NIST Technical Note 1870

\title{
Simulation of a Residential Wind Driven Basement Fire - Riverdale Heights, MD
}

Craig G. Weinschenk

Kristopher J. Overholt Daniel Madrzykowski

This publication is available free of charge from: http://dx.doi.org/10.6028/NIST.TN.1870 

NIST Technical Note 1870

\section{Simulation of a Residential Wind Driven Basement Fire - Riverdale Heights, MD}

Craig G. Weinschenk

Kristopher J. Overholt

Daniel Madrzykowski

Fire Research Division

Engineering Laboratory

This publication is available free of charge from: http://dx.doi.org/10.6028/NIST.TN.1870

February 2015

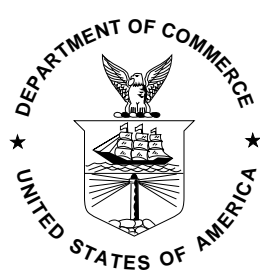

U.S. Department of Commerce Penny Pritzker, Secretary 
Certain commercial entities, equipment, or materials may be identified in this document in order to describe an experimental procedure or concept adequately. Such identification is not intended to imply recommendation or endorsement by the National Institute of Standards and Technology, nor is it intended to imply that the entities, materials, or equipment are necessarily the best available for the purpose.

\section{National Institute of Standards and Technology Technical Note 1870 Natl. Inst. Stand. Technol. Tech. Note 1870, 49 pages (February 2015) CODEN: NTNOEF}

This publication is available free of charge from: http://dx.doi.org/10.6028/NIST.TN.1870 


\section{Contents}

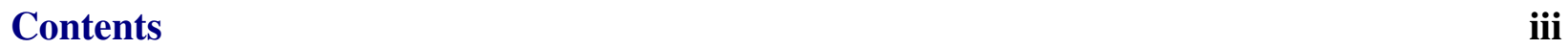

$\begin{array}{ll}\text { List of Figures } & \text { v }\end{array}$

List of Tables

List of Acronyms viii

$\begin{array}{ll}\text { List of Symbols } & \text { ix }\end{array}$

1 Introduction $\quad 1$

2 Fire Incident Summary $\quad 2$

3 Model Description $\quad 4$

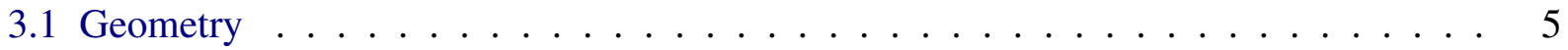

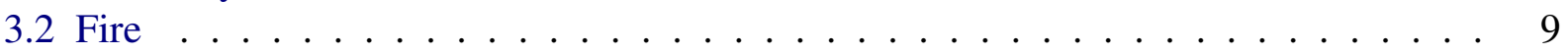

3.3 Materials . . . . . . . . . . . . . . . . . . 13

3.4 Ventilation . . . . . . . . . . . . . . . . . . 13

3.5 Numerical Mesh . . . . . . . . . . . . . . . . . . . . . . . . . . . . . . . . . . . . . . . . .

3.6 Summary of Model Input Parameters . . . . . . . . . . . . . . . . . 18

4 Model Results $\quad 19$

4.1 Heat Release Rate . . . . . . . . . . . . . . . . . . . . . . . . 21

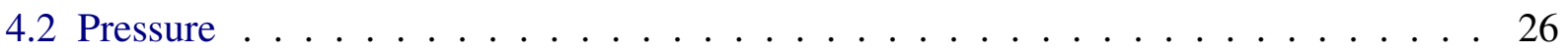

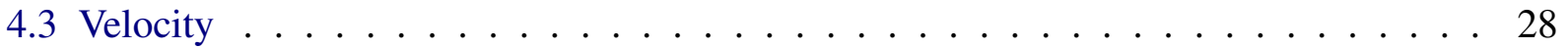

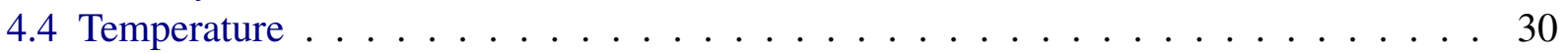

5 Discussion $\quad 32$

5.1 Simulated Flow Path . . . . . . . . . . . . . . . . . . 32

5.2 Assessing the Hazard . . . . . . . . . . . . . . . . . . . 36

5.3 Tactical Considerations . . . . . . . . . . . . . . . . . 40

6 Summary $\quad 42$

7 Acknowledgments $\quad 43$ 
A Dimensioned Drawings 


\section{List of Figures}

3.1 Photograph and computer model rendering of terrain. . . . . . . . . . . . 5

3.2 Plan view of basement (top) and first (bottom) floor of structure. . . . . . . . . . . 7

3.3 Photographs showing the front (top) and rear (bottom) exterior of the structure after the incident. . . . . . . . . . . . . . . . . . . 8

3.4 Plan view of basement indicating fire location. . . . . . . . . . . . . . . 9

3.5 Prescribed HRR vs. time for the simulation. . . . . . . . . . . . . . . . . 12

3.6 Front (top) and rear (bottom) of the structure with $10 \mathrm{~cm}$ computational mesh surrounding the structure and $20 \mathrm{~cm}$ mesh to the left and right of the structure. . . . 16

3.7 Overhead front-left side of the structure within the computational domain. . . . . . 17

4.1 Comparison of prescribed and calculated interior HRRs from the FDS simulation. . 21

4.2 Prescribed and total calculated HRRs vs. time from the simulation. . . . . . . . . . 22

4.3 External post-fire image of damage to the basement (top) and FDS model showing external fire prior to the front door of the structure being opened (bottom). . . . . . 23

4.4 Prescribed, calculated domain, and calculated basement HRRs vs. time from the simulation. . . . . . . . . . . . . . . . . . . . . 24

4.5 First floor calculated HRR vs. time from the simulation. . . . . . . . . . . 25

4.6 Calculated pressure on first floor $1 \mathrm{~s}$ before and after the front door opened. . . . . 27

4.7 Calculated velocity on the first floor $1 \mathrm{~s}$ before and after the front door opened. . . . 29

4.8 Calculated temperature on the first floor $1 \mathrm{~s}$ before the front door opened. . . . . . 30

4.9 Calculated temperature on the first floor $1 \mathrm{~s}$ after the front door opened. . . . . . 31

4.10 Calculated temperature on first floor $5 \mathrm{~s}$ after the front door opened. . . . . . . . 31

5.1 Flow path vectors at the front door and top of the stairwell $1 \mathrm{~s}$ before the front door was opened. . . . . . . . . . . . . . . . . . 33

5.2 Flow path vectors at the front door and the top of stairwell $1 \mathrm{~s}$ after the front door was opened. . . . . . . . . . . . . . . . . . 33

5.3 Flow path vectors at the front door and the top of the stairwell at the estimated time of first floor entry. . . . . . . . . . . . . . . . . . . . 34

5.4 Flow path vectors at the front door and the top of stairwell $1 \mathrm{~s}$ before the front door was closed. . . . . . . . . . . . . . . . . . 35

5.5 Flow path vectors at the front door and the top of stairwell $1 \mathrm{~s}$ after the front door was closed. . . . . . . . . . . . . . . . . . 35 
5.6 Interior temperature contours $1 \mathrm{~s}$ before the front door was opened (21:13:59). The top snapshot shows temperatures on the first floor and basement on the plane that runs through the center of the front door. The bottom snapshot shows temperatures on the first floor and basement on the plane that runs through the center of the interior stairwell doorway. . . . . . . . . . . . . . . . . . 37

5.7 Interior temperature contours $1 \mathrm{~s}$ after the front door was opened (21:14:01). The top snapshot shows temperatures on the first floor and basement on the plane that runs through the center of the front door. The bottom snapshot shows temperatures on the first floor and basement on the plane that runs through the center of the

5.8 Interior stairwell doorway. $\ldots \ldots \ldots \ldots \ldots \ldots \ldots . \ldots \ldots$ The top snapshot shows temperatures on the first floor and basement on the plane that runs through the center of the front door. The bottom snapshot shows temperatures on the first floor and basement on the plane that runs through the center of the interior stairwell doorway. . . . . . . . . . . . . . . . . 39

A.1 Dimensioned drawing of the basement. . . . . . . . . . . . . . . . . . . 48

A.2 Dimensioned drawing of the first floor. . . . . . . . . . . . . . . . . 49 


\section{List of Tables}

2.1 Abridged approximate fire event timeline. . . . . . . . . . . . . 3

3.1 Timeline of ventilation changes in the simulation. . . . . . . . . . . . . . . 14

3.2 Relevant fire model input parameters. . . . . . . . . . . . . . . . 18

4.1 Fire incident and simulation event timeline. . . . . . . . . . . . . . 20

5.1 Flow path related LODD/LODI incidents. . . . . . . . . . . . . . . . 41 


\section{List of Acronyms}

$\begin{array}{ll}\text { EMS } & \text { Emergency Medical Services } \\ \text { FDS } & \text { Fire Dynamics Simulator } \\ \text { HGL } & \text { Hot Gas Layer } \\ \text { HRR } & \text { Heat Release Rate } \\ \text { HRRPUA } & \text { Heat Release Rate per Unit Area } \\ \text { LODD } & \text { Line of Duty Death } \\ \text { NIST } & \text { National Institute of Standards and Technology } \\ \text { PPE } & \text { Personal Protective Equipment } \\ \text { SCBA } & \text { Self Contained Breathing Apparatus } \\ \text { SFPE } & \text { Society of Fire Protection Engineers }\end{array}$




\section{List of Symbols}

$\begin{array}{ll}\mathrm{ft} & \text { foot } \\ \mathrm{m} & \text { meter } \\ \mathrm{min} & \text { minute } \\ \mathrm{Pa} & \text { Pascal } \\ \mathrm{psi} & \text { pound per square inch } \\ \mathrm{S} & \text { second } \\ \mathrm{W} & \text { Watt } \\ k & \text { thermal conductivity } \\ \rho & \text { density } \\ c_{p} & \text { specific heat }\end{array}$




\section{Abstract}

Fire Dynamics Simulator (FDS), which is a fire model that is developed and maintained by the National Institute of Standards and Technology (NIST), was used to provide insight into the dynamics of a fire that occurred on February 24, 2012, within a single-story, single-family residential structure in Riverdale Heights, MD, that resulted in the serious injury of two Price George's County firefighters. The inputs for the FDS simulation are documented in this report and are based on the fire scenario, including the building geometry, interior furnishings, and ventilation conditions. The fire started in the basement which generated ventilation limited (fuel rich) fire conditions in the basement area. After the front door was opened, the interior stairwell, aided by strong winds blowing into the basement, acted as a chimney for hot gases in the basement to flow towards regions of lower pressure, out through the front door. The temperature of the gases in the interior stairwell was estimated to be in excess of $400^{\circ} \mathrm{C}\left(750^{\circ} \mathrm{F}\right)$. Two firefighters were located in the flow path between the interior stairwell door and the front door of the structure, were exposed to these elevated temperatures, and suffered serious burn injures. Five additional firefighters were injured during fire operations on the first floor. 


\section{Section 1}

\section{Introduction}

Part of the function of the Fire Research Division at the National Institute of Standards and Technology (NIST) is to develop and apply technology, measurements, and standards to improve the understanding of the behavior, prevention, and control of fires to enhance fire fighting operations and equipment, fire suppression, fire investigations, and disaster response. NIST has previously used the Fire Dynamics Simulator (FDS) fire model to provide insight into the fire development and thermal conditions of fires that have resulted in line of duty deaths (LODDs) [1-7]. The objective of these studies has been to improve the safety and effectiveness of firefighters.

On February 24, 2012, a fire in an uninhabitated residential structure injured seven Prince George's County firefighters. NIST examined the fire dynamics of this incident at the request of the Prince George's Country Fire/Emergency Medical Services (EMS) Department. Computer simulations of the fire incident were conducted using the NIST Fire Dynamics Simulator [8] and Smokeview [9] software to provide insight into the fire development and thermal conditions that likely existed inside the residence during the fire. The specific objectives of the simulations detailed in this report are:

1. To examine the effect of the flow path (including temperature, pressure, and fire conditions) in this single-story residential structure with a basement using physics-based calculations.

2. To provide visualizations of the fire behavior that are representative of the conditions that members of the Prince George's Fire Department likely experienced during the course of their interior operations.

3. To provide a basis for analyzing tactical operations in terms of fire dynamics.

This document describes the input and the results of the FDS (version 6.1.1) simulations. The simulations were developed using a combination of knowledge of the fire scenario and appropriate engineering approximations and assumptions. Analysis of the simulation results focuses on the hazardous conditions that developed following the development of a flow path inside of the structure. This document is organized as follows: Section 2 provides a summary of the fire incident, Section 3 describes the relevant model input parameters and assumptions that were used to develop the simulations, Section 4 presents the simulation results, and Section 5 discusses the simulation results as they relate to firefighter safety and effectiveness. Appendix A contains dimensioned drawings of the basement and first floor of the structure. 


\section{Section 2}

\section{Fire Incident Summary}

The account of events for this incident was documented by the Safety Investigation Team of the Prince George's County Fire/EMS Department [10]. At 21:11 hours on February 24, 2012 Prince George's Fire/EMS Department responded to a residential structure fire in Riverdale Heights, Maryland with a fire in the basement [10]. For the purpose of this analysis, the details regarding the timeline are considered to be approximate values. The Prince George's County report [10] includes narratives of actions of the response personnel. Note that term following the apparatus number (e.g. Truck 809 Can) refers to the seating assignment and operational duties of the firefighters on board. The following narrative of the incident, focused on the events which led to serious burn injuries to two emergency-personnel, was taken from the Prince George's County report [10]:

Truck 809 responded from quarters, as the first due truck company, and arrived on 57th Avenue right behind Engine 807B. When Truck 809 stopped to let Engine 807B layout, Truck 809 Can dismounted the truck and had to walk up the street as it pulled away. Truck 809 Officer observed a lot of smoke moving extremely fast through the front yard and across the street upon exiting the truck. Truck 809 Officer and Truck 809 Forcible Entry proceeded directly to the front door ... of the structure. Both of them entered the structure with full PPE, including SCBA, but without the protection of a hose line. Truck 809 Officer and Truck 809 Forcible Entry began primary searches on the first floor. At some point during the primary search, as conditions worsened, the front door closed, trapping Truck 809 Officer and Truck 809 Forcible Entry inside the structure. This situation could not have occurred if a charged hose line was operating inside the structure at the time the door slammed shut. They were the only firefighters operating on the first floor at that time.

Truck 809 Forcible Entry was unable to self-evacuate, and remained trapped inside. Due to rapidly deteriorating conditions, Truck 809 Officer was forced to self-rescue through another small window on [the front of the structure].

After exiting the structure, Truck 809 Officer [alerted other firefighters] that a firefighter was trapped inside. Truck 809 Officer then proceeded to the front door ... in an attempt to search for and rescue Truck 809 Forcible Entry, who was trapped inside. At this point multiple firefighters on the exterior assisted Truck 809 Officer in the search, rescue, and removal of Truck 809 Forcible Entry. Both Truck 809 Officer and Truck 809 Forcible Entry sustained serious injuries and were transported to MedStar/Washington Hospital Center. 
From a combination of on-scene video and the narrative accounts from the Prince George's County Fire/EMS Department report [10], Table 2.1 shows an overview of the timeline of events. Table 2.1 represents the best estimate of the events.

Table 2.1: Abridged Prince George's Fire/EMS approximate fire event timeline [10].

\begin{tabular}{|c|c|}
\hline $\begin{array}{l}\text { Incident Time } \\
\text { [hh:mm:ss] }\end{array}$ & Fire Behavior / Fireground Operation \\
\hline 21:08:26 & First 911 call is made. \\
\hline 21:11:03 & $\begin{array}{l}\text { Dispatch for a "box" alarm assignment- four engine com- } \\
\text { panies, two truck companies, one rescue squad, and a com- } \\
\text { manding officer. }\end{array}$ \\
\hline $21: 12: 55$ & First unit (Engine 807B) arrived on-scene. \\
\hline $21: 13: 44$ & Volunteer Chief 809A establishes incident command (IC). \\
\hline $21: 13: 56$ & Truck 809 arrived on-scene. \\
\hline 21:14:00 & Front door opened. \\
\hline $21: 14: 42$ & Truck 809 personnel enter structure. \\
\hline $21: 15: 47$ & Basement door opened and water applied to fire. Front door blown closed. \\
\hline $21: 15: 51$ & Lower pane of front egress window broken. \\
\hline 21:16:01 & Top pane of front egress window broken. \\
\hline $21: 16: 16$ & Truck 809 officer bailout through front window. \\
\hline 21:16:44 & Front door opened. \\
\hline $21: 17: 15$ & Truck 809 forcible entry firefighter rescued. \\
\hline
\end{tabular}




\section{Section 3}

\section{Model Description}

Fire Dynamics Simulator [8] is a computational fluid dynamics (CFD) model that solves a form of the Navier-Stokes equations appropriate for low-speed, thermally driven flow with an emphasis on smoke and heat transport from fires. Within a CFD model, the room or building is divided into small three-dimensional rectangular control volumes or computational cells. The cells are contained together within one larger volume known as a computational domain. The CFD model computes the density, velocity, temperature, pressure, and species concentration of the gas in each cell. Based on the laws of conservation of mass, momentum, and energy, the model tracks the generation and movement of fire gases. One of the most important advantages of FDS is that it is mathematically verified [11] and validated against fire test data to ensure that it provides the expected results, given sufficient input data [12]. A complete description of the FDS model is provided in the FDS Technical Reference Guide [13].

Smokeview is a software tool designed to visualize simulation results from FDS [9]. Smokeview visualizes smoke and other attributes of the fire simulation using traditional scientific methods such as displaying tracer particle flow, two dimensional (2D) or three dimensional (3D) shaded contours of gas flow data such as temperature and flow vectors showing flow direction and magnitude. Smokeview allows the fire and fire movement to be visualized. This is done by displaying a series of partially transparent planes where the transparencies in each plane (at each grid node) are determined from soot densities computed by FDS. Smokeview also visualizes static data at particular times using 2D or 3D contours of data such as temperature and flow vectors showing flow direction and magnitude.

Input data from various sources must be collected and documented to simulate a fire using FDS or any other fire model. For the simulation results presented in this document, information was obtained from two primary sources. The following information was gathered from the fire scene: the geometry of the building and the compartments being modeled, the size and location of exterior and interior ventilation openings, and documentation of fire damage to the building. The following information was gathered from witnesses, first responders, reports, and recorded media such as fire ground radios or videos: information on the timing of the fire development, the sequence and approximate timing of ventilation openings to the outside, and weather conditions at the time of the fire.

The analysis of the simulation results is focused on the impact of ventilation. Specifically on the interior conditions of the first floor following the establishment of a flow path through door control and how wind impacted these conditions. Based on the goals of the analysis and the information 
collected, several engineering approximations were made. For example, heavy smoke conditions were reported at the front of the house at the time of arrival [10]; however, the exact ignition time, fire growth rate, and heat release rate (HRR) of the fire were not known. The ignition time and growth rate were estimated to reduce the amount of required calculation time while adhering to the event timeline (Table 2.1) and documented observations. The HRR of the fire was estimated using documentation of the potential fuel load within the structure and relevant literature.

\subsection{Geometry}

The structure involved in this fire incident was a single-story, single-family structure with a basement. The structure was platform-framed wood construction with a gable roof. ${ }^{1}$ The structure had a first floor footprint of $9.14 \mathrm{~m}(30 \mathrm{ft})$ by $7.77 \mathrm{~m}(25.5 \mathrm{ft})$ with the basement being slightly smaller,

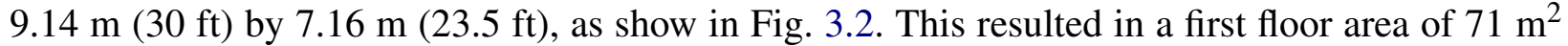
$\left(764 \mathrm{ft}^{2}\right)$ and a basement floor area of $65 \mathrm{~m}^{2}\left(700 \mathrm{ft}^{2}\right)$. The interior walls were composed of gypsum board over wood framing [10]. There was a single flight of stairs in the center of the structure which connected the first floor to the basement.

The structure was built on a sloped landscape such that on the front side of the structure the first floor was located at street level but the basement was below street level (Fig. 3.1). On the rear side of the structure, the slope allowed the basement to be a walkout. Therefore, access to the structure could be made on the front side to the first floor and on the rear side to the basement.
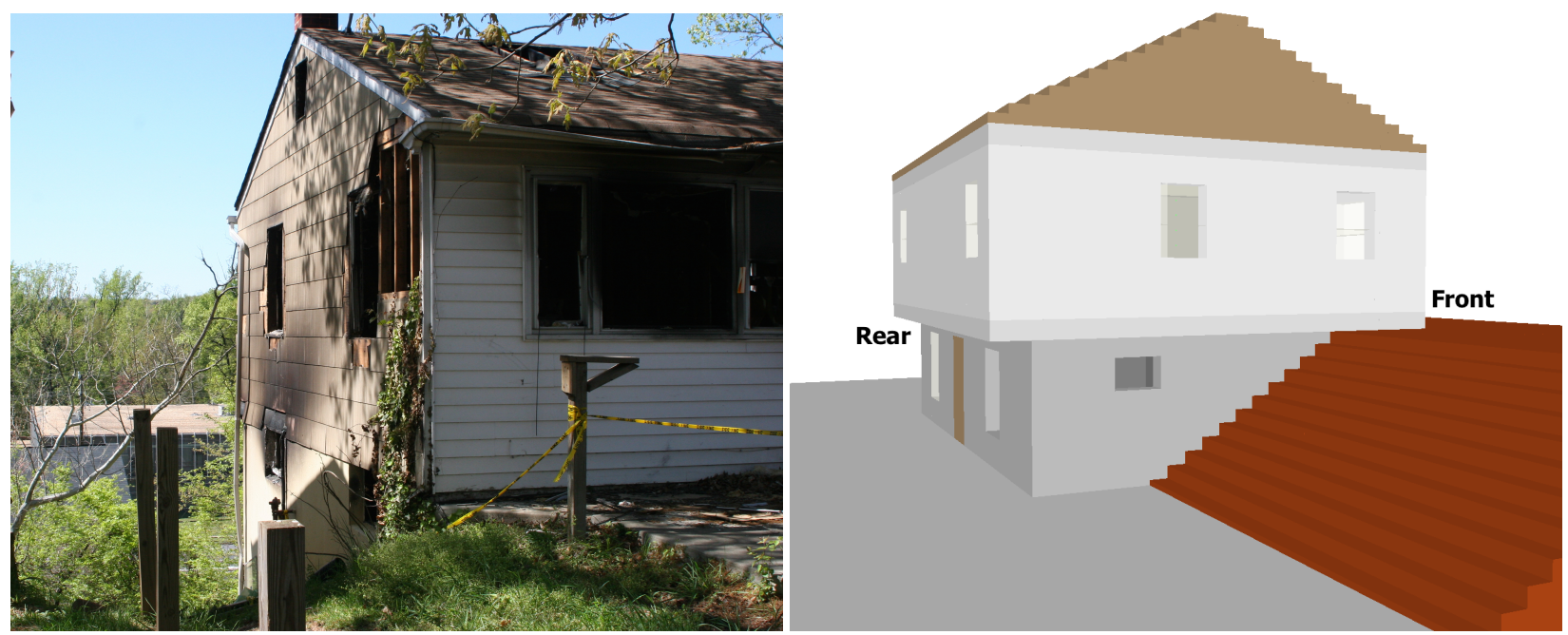

Figure 3.1: Photograph taken from front side street level showing the slope down to basement on the rear side of the structure (left) and Smokeview rendering of model representation of sloped landscape (right).

The fire, which is described in Section 3.2, started in the basement and spread to the stairs

\footnotetext{
${ }^{1}$ Platform-framed construction means that floor joists are completely covered with a sub-floor. This forms a platform from which walls are built.
} 
which connect to the first floor. The door at the top of the stairs was open at the time of the fire. Discussion of the fire's impact on the interior conditions is provided in Section 4. Figure 3.3 shows the exterior of the front and rear of the structure after the incident. Note that the majority of the damage occurred in the basement of the structure. Fully dimensioned drawings of the interior of the basement and first floor are shown in Figs. A.1 and A.2, respectively. 

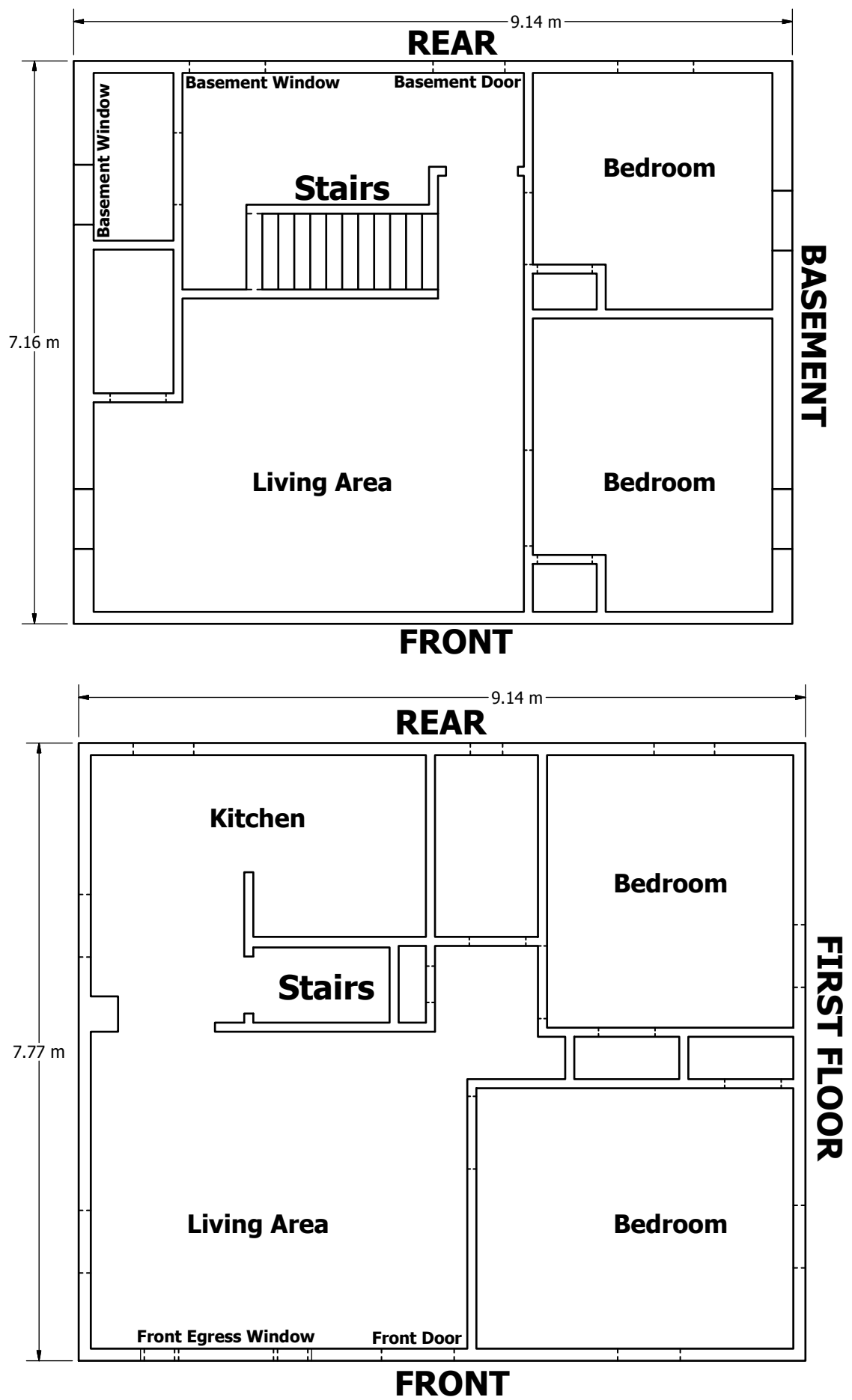

Figure 3.2: Plan view of basement (top) and first (bottom) floor of structure. Stairs and key windows and doors are identified using measurements collected by NIST. 


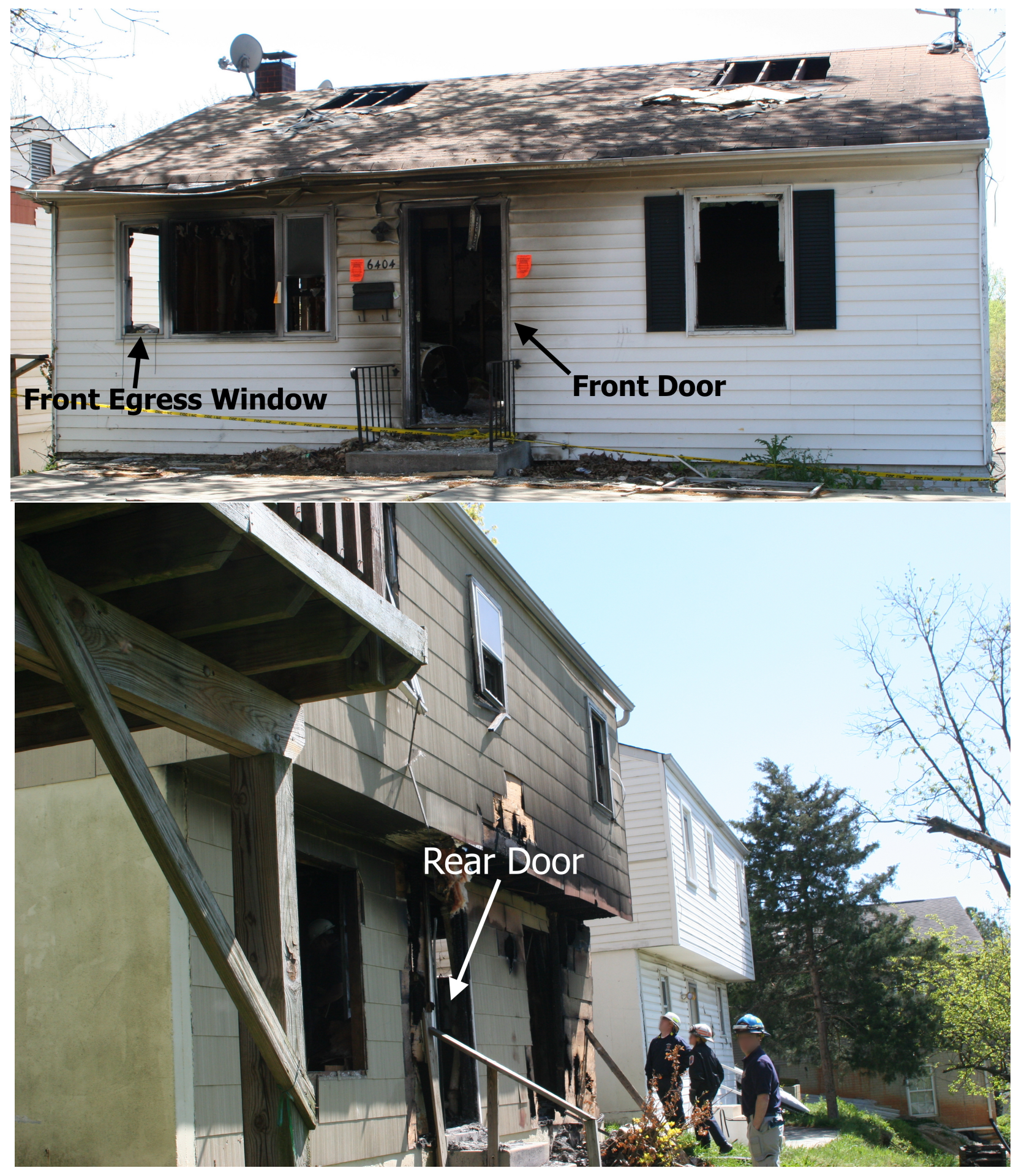

Figure 3.3: Photographs showing the front (top) and rear (bottom) exterior of the structure after the incident. 


\subsection{Fire}

To estimate the type of fuel, fire size, and structure ventilation, on-scene videos and post-incident reports were used. Based on these sources of information, the FDS model includes two source fire locations in the basement: one fire in the kitchen area and one in the adjacent bathroom (Fig. 3.4). At the time of the fire, the structure was unfurnished so the the dominant fuel was wood: wood paneling on walls, exposed ceiling joists, sub-floor, cabinets, and stairs.

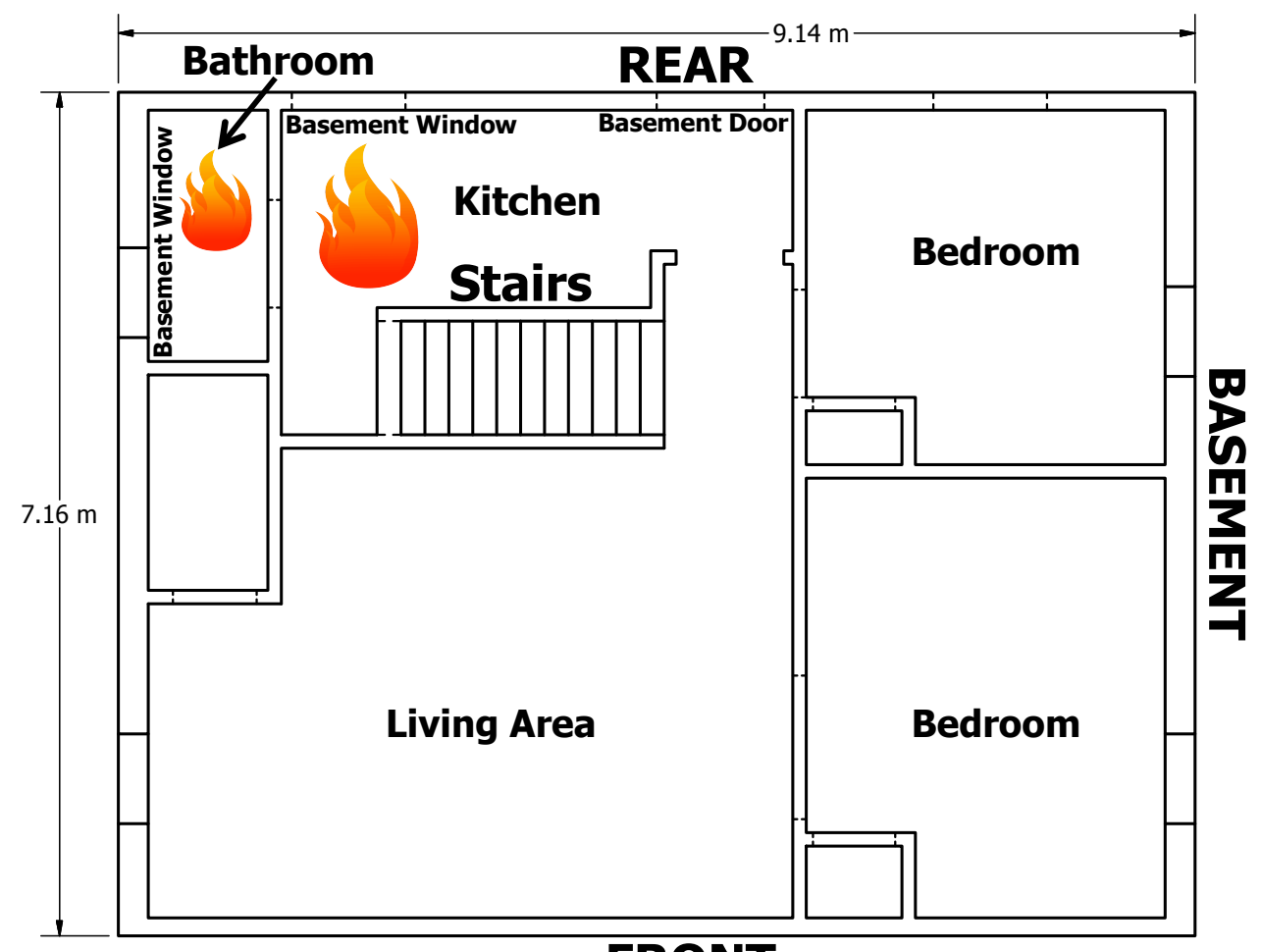

FRONT

Figure 3.4: Plan view of the basement indicating the location of the two fires in the FDS model.

Wood fuel can be represented by the chemical formula, $\mathrm{CH}_{1.7} \mathrm{O}_{0.74} \mathrm{~N}_{0.002}$, with specified yields of carbon monoxide $\left(y_{\mathrm{CO}}=0.004 \mathrm{~kg} / \mathrm{kg}\right)$ and soot $\left(y_{\mathrm{C}}=0.015 \mathrm{~kg} / \mathrm{kg}\right)$ [14]. The product yields are expressed in terms of the amount of carbon monoxide or soot emitted per unit mass of fuel consumed $(\mathrm{kg} / \mathrm{kg}$ ) and can be found in the Society of Fire Protection Engineers (SFPE) Handbook [14]. A balanced chemical reaction for wood combustion can be written as:

$$
\begin{aligned}
\mathrm{CH}_{1.7} \mathrm{O}_{0.74} \mathrm{~N}_{0.002}+4.91\left(0.208 \mathrm{O}_{2}+0.783 \mathrm{~N}_{2}+0.387 \mathrm{E}-3 \mathrm{CO}_{2}+0.834 \mathrm{E}-2 \mathrm{H}_{2} \mathrm{O}\right) \\
\rightarrow 5.74\left(0.636 \mathrm{E}-3 \mathrm{CO}+0.168 \mathrm{CO}_{2}+0.155 \mathrm{H}_{2} \mathrm{O}+0.670 \mathrm{~N}_{2}+0.613 \mathrm{E}-2 \mathrm{C}\right)
\end{aligned}
$$

The value for the heat of combustion of wood used in this simulation was $16,400 \mathrm{~kJ} / \mathrm{kg}$, based on data provided in the SFPE Handbook [14]. The heat of combustion quantifies the amount of energy per unit mass of the fuel. The following text defines Eq. 3.1 for an FDS input file with the desired fuel and reaction properties discussed above: 


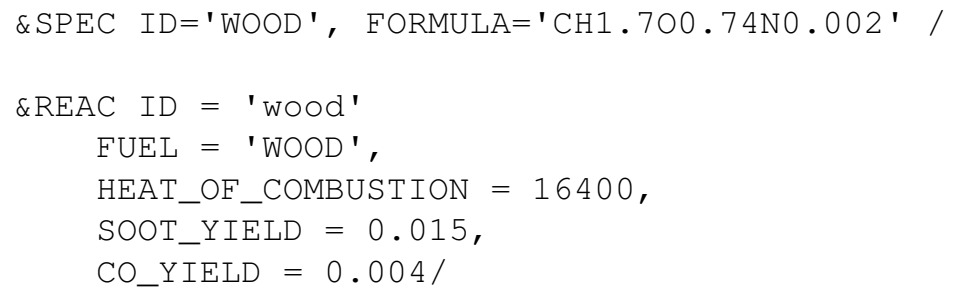

Note that using the input lines above will invoke the simple chemistry reaction mechanism in FDS in which fuel and air react to form only $\mathrm{CO}_{2}, \mathrm{CO}, \mathrm{H}_{2} \mathrm{O}$, soot, and $\mathrm{N}_{2}$. If the inclusion for other combustion products is desired, then the user must explicitly define those species and the chemical reaction that produces them [8]. Based on the above input lines, FDS uses the default, mixing-controlled fast chemistry combustion model. This mechanism states that the rate of fuel consumption is proportional to both the local limiting reactant concentration and the local rate of mixing. Extinction is based on the critical flame temperature approach [13]. While FDS provides users with the option to use a more complex finite-rate combustion mechanism, there is not sufficient evidence in this case to justify deviating from the default specifications.

To estimate the heat release rate per unit area (HRRPUA) of wood, Babrauskas and Grayson [15] conducted experiments in a cone calorimeter ${ }^{2}$ to determine the 5-min average of the HRRPUA for several different types of wood over a range of radiant heat fluxes. The results of that study indicate that the HRRPUA for different types of wood is approximately $50 \mathrm{~kW} / \mathrm{m}^{2}$.

To calculate the total fire size, the appropriate burning area of the basement needed to be determined. Based on the floor plan of the structure and post-incident images, two distinct fires were considered: 1 source in the basement bathroom and 1 source in the basement kitchen. The bathroom fire was estimated to be comprised of wood paneling along the four walls $\left(17.3 \mathrm{~m}^{2}\right.$ or $\left.186 \mathrm{ft}^{2}\right)$ and wood subfloors and studs along the ceiling $\left(2.9 \mathrm{~m}^{2}\right.$ or $\left.31 \mathrm{ft}^{2}\right)$. This resulted in $20.2 \mathrm{~m}^{2}\left(217 \mathrm{ft}^{2}\right)$ of wood burning surface area or a $1 \mathrm{MW}$ fire using a $50 \mathrm{~kW} / \mathrm{m}^{2}$ HRRPUA. The remainder of the wood combustable load in the basement was lumped into the localized kitchen fire. The ceiling and wall areas included in the basement kitchen, stairway, and main living area totaled approximately $86 \mathrm{~m}^{2}\left(926 \mathrm{ft}^{2}\right)$. This resulted in a $4.3 \mathrm{MW}$ fire.

Initial simulations were conducted using a HRR for the two fires totaling 5.3 MW, however, the fire behavior did not align with observations made during the fire incident or post-incident images. Specifically there was insufficient fuel to drive the basement to an underventilated condition. One reason is that while the structure was unoccupied at the time of the fire [10], there were additional fuels that were not accounted for: transient fuels, sparse kitchen cabinetry, and an unknown bathroom vanity among other fuels. A second reason is that the $50 \mathrm{~kW} / \mathrm{m}^{2}$ HRRPUA used to estimate the fire size does not account for an observed increase in burning rate during wind driven fires $[17,18]$. It is not clear how to quantify the impact of wind on burning rate within a structure from first principles, so several iterations of the model with increased fire sizes were run. The final estimated fire size was a 1.8 MW fire in the bathroom and a 6.8 MW fire in the kitchen. This resulted in a total peak specified fire size of 8.6 MW.

Since the time at which the fire started is not known relative to the notification of a fire or how fast the fire spread, several simplifications were made. The fires started at the beginning of the

\footnotetext{
${ }^{2}$ The cone calorimeter is an experimental apparatus used to gather data about ignition time, mass loss, combustion products, and heat release rate among other properties associated with burning small samples of materials [16].
} 
simulation and increased to a value of $8.6 \mathrm{MW}$ in $10 \mathrm{~s}$. The 10 -s ramp up time was used to prevent abrupt changes in the velocity at the fire boundary condition in FDS. Since the actual ignition time is unknown, the fire was ramped quickly to reflect the conditions determined from reports and post-incident images. The second assumption is that the sources of the gas phase wood fuel have constant areas at fixed locations in the basement (1 source for the kitchen, 1 source for the bathroom). At $207 \mathrm{~s}$, using a simple decay model, the fire size decreases linearly to $25 \%$ of its peak value in $60 \mathrm{~s}$. This is to account for the impact of firefighters putting water on the basement fire (Table 2.1). The following lines define the source fires in the FDS input file:

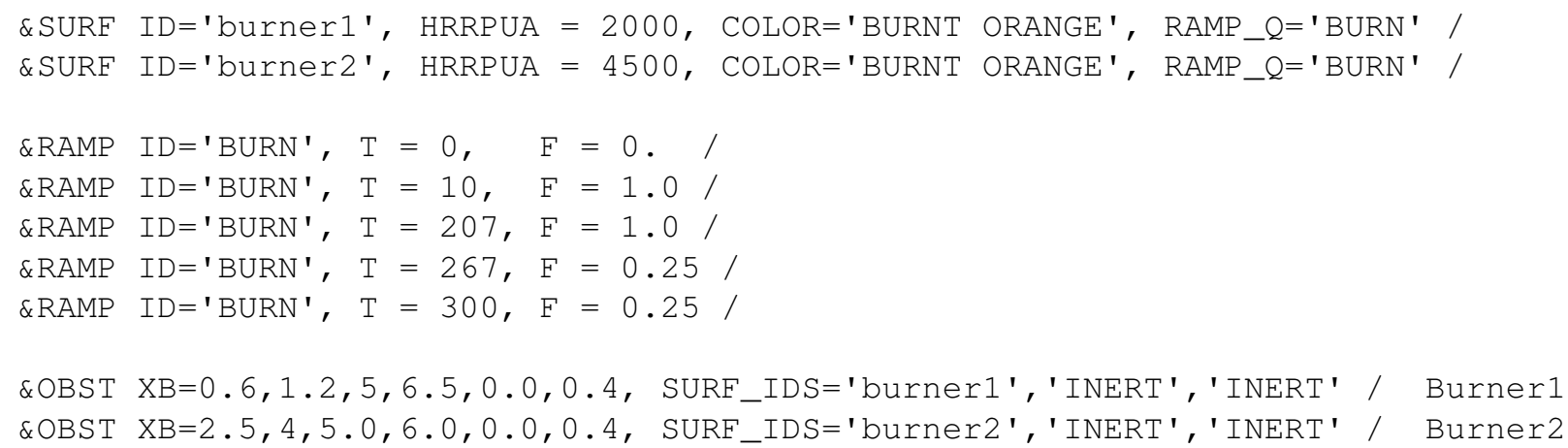

Note that the coordinates here are unique for the vents are specific to the input files used for these simulations. The key point is the 2-D planar area.

Figure 3.5 shows the overall prescribed design fire for this scenario, which is the sum of the HRRs of the two source fires. In this figure, the text indicates the prescribed steady peak HRR and the decay phase associated with firefighter water application. Note that the prescribed HRR can be different than the simulated HRR calculated by FDS based on the amount of available fuel, oxygen, and ventilation. A comparison of the prescribed HRR and the simulated HRR is discussed in Section 4.1. 


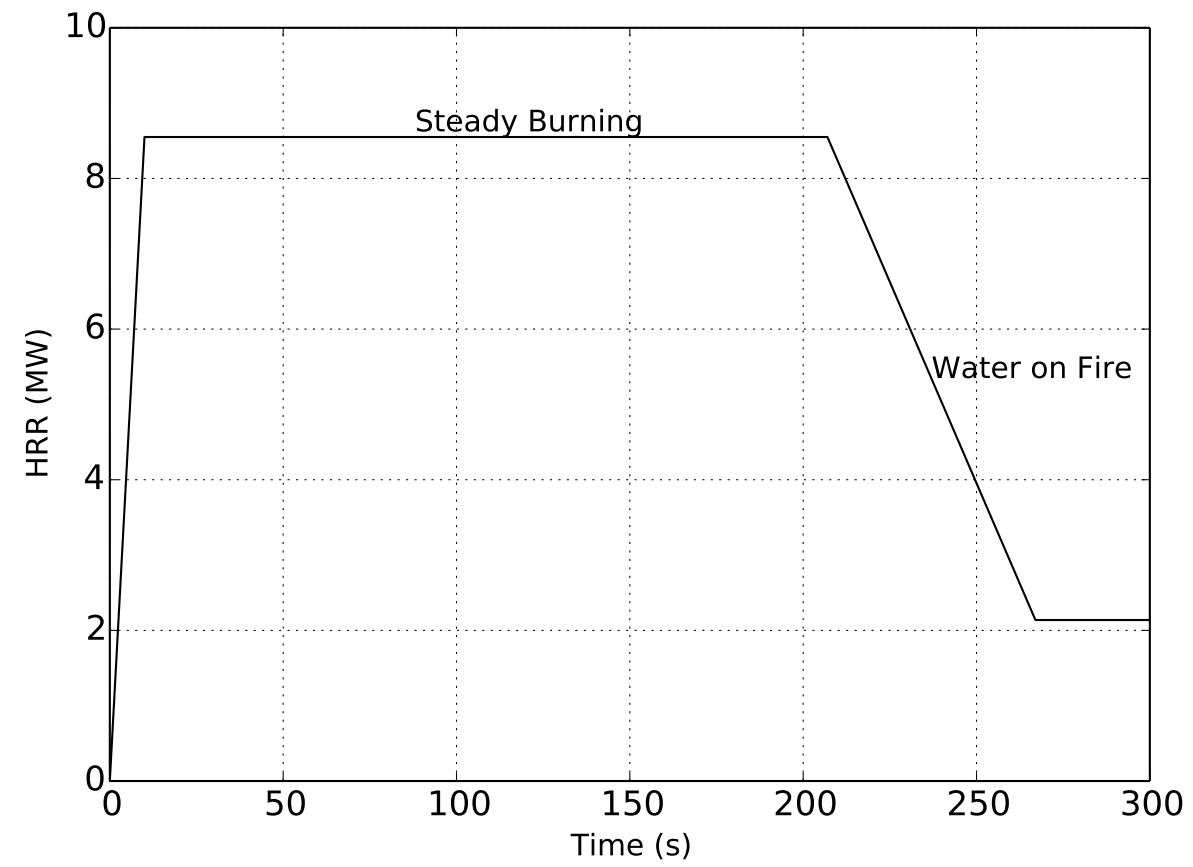

Figure 3.5: Prescribed HRR vs. time for the simulation. The text labels indicate the prescribed steady peak HRR and the decay phase associated with firefighter water application. Time zero represnts 21:21:20, see Table 4.1. 


\subsection{Materials}

While the fires were represented as fuel sources with a constant area (Section 3.2), from a heat transfer perspective, it is important to define the material properties (density, thermal conductivity, and specific heat) to account for heat transfer and energy storage in the ceiling, walls, and floor. In this study, the material properties of gypsum board [19] were specified on the finished walls and ceilings on the main two floors of the structure, and the material properties of wood [20] were specified on the unfinished portions of the structure. The following lines define these materials in the FDS input file:

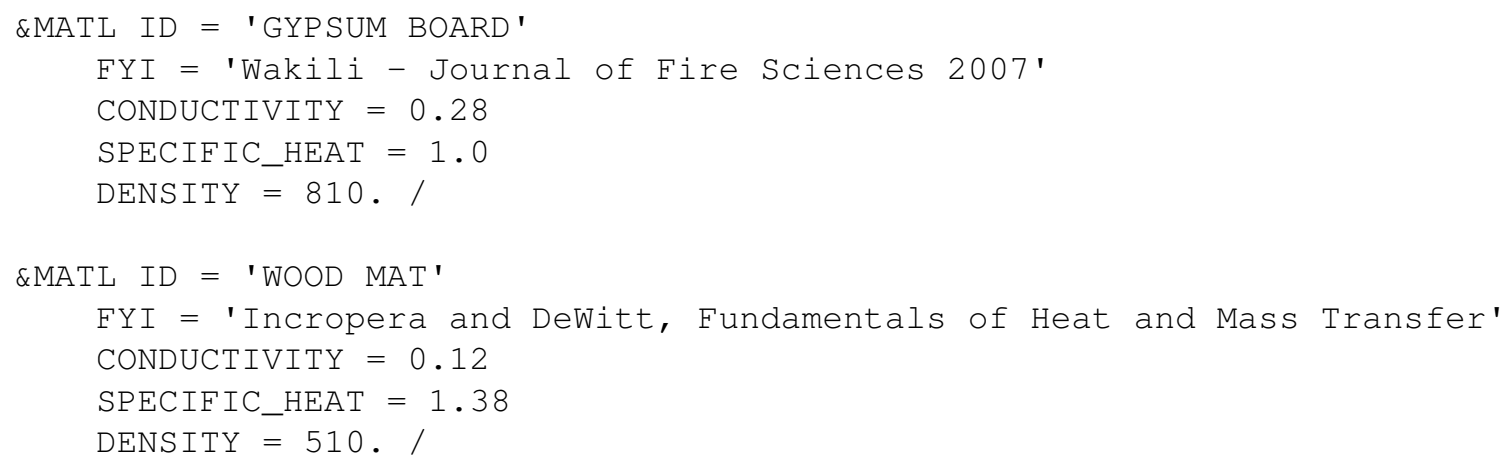

\subsection{Ventilation}

The simulation in this study accounts for changes in the ventilation due to a combination of fire department operations (opening doors), fire acting on the structure (fire breaching windows) and wind (restricting flow, closing doors). The ventilation times and ventilation areas represent the best understanding of the incident. The estimated times of ventilation changes for doors and windows are provided in Table 3.1.

During the time when the firefighters exited the structure or were rescued from the structure, the state of some windows and doors in the structure was known. The state of the vents (opened versus closed) resulted in the establishment of a flow path in the interior stairwell leading from the basement to the first floor. The exact time of operation for other doors/windows was not known. Therefore, the two basement windows on the left rear corner of the structure were assumed to be open at the start of the simulation. The states of the front door and front window were specified at certain times based on observations (i.e. forcible entry, wind effects, forced window breakage) from post-incident reports.

Structure leakage has been shown to be important when modeling enclosure fires [21]. The open rear basement windows at the start of the simulation were significantly larger than the typical total effective area of leakage of a structure of this type. Therefore, any leakage in the structure would have a negligible impact on the fluid mechanics within the structure and is not included in this study.

In addition to the state of openings within the structure, outlined in Table 3.1 , an $8.9 \mathrm{~m} / \mathrm{s}$ (20 mph) wind velocity boundary condition was assumed. The flow direction of the wind was asasumed from the rear toward the front of the structure, perpendicular to the rear of the structure. 
Table 3.1: Timeline of ventilation changes in the simulation.

\begin{tabular}{lllll}
\hline $\begin{array}{l}\text { Baseline } \\
\begin{array}{l}\text { Simulation } \\
{[\mathrm{s}]}\end{array}\end{array}$ & $\begin{array}{l}\text { Ventilation } \\
\text { Area } \\
{\left[\mathrm{m}^{2}\right]}\end{array}$ & Type & $\begin{array}{l}\text { State of } \\
\text { Opening }\end{array}$ & $\begin{array}{l}\text { Side of } \\
\text { Structure }\end{array}$ \\
\hline 0 & 1.40 & Window & Opened & Rear \\
0 & 0.39 & Window & Opened & Left \\
100 & 1.84 & Door & Opened & Front \\
207 & 1.84 & Door & Closed & Front \\
207 & 1.84 & Door & Opened & Rear \\
211 & 0.26 & Window & Opened & Front \\
221 & 0.26 & Window & Opened & Front \\
267 & 1.84 & Door & Opened & Front \\
\hline
\end{tabular}

Based on local weather conditions, mean wind velocities ranged between $4.5 \mathrm{~m} / \mathrm{s}(10 \mathrm{mph})$ and $8.9 \mathrm{~m} / \mathrm{s}(20 \mathrm{mph})$ with gusts up to $13.4 \mathrm{~m} / \mathrm{s}(30 \mathrm{mph})$ with a direction that angled toward the back left of the structure [10]. The following lines define the wind boundary condition in the FDS input file:

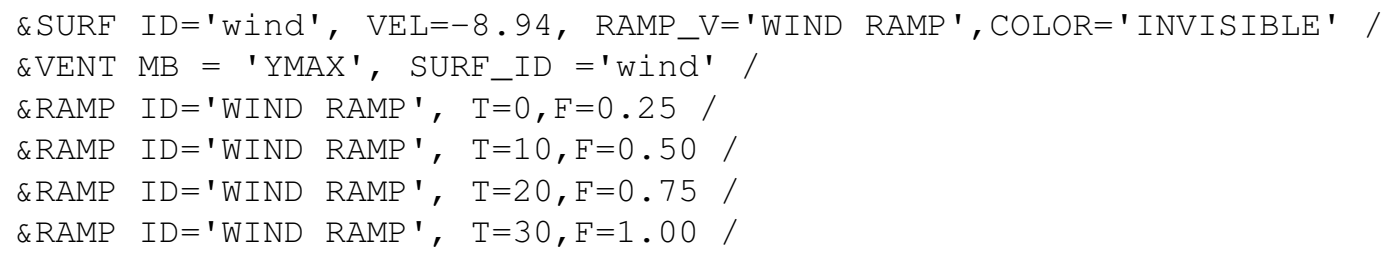

Note that there is a $30 \mathrm{~s}$ ramp time to reach peak wind speed. This was inlcuded to prevent an abrupt change at the FDS domain boundary. Since the front door does not open until $100 \mathrm{~s}$ into the simulation there was sufficient time to for the airflow to stabilize.

\subsection{Numerical Mesh}

For the simulation, a measure of how well the flow field is resolved can be estimated by using the non-dimensional expression $D^{*} / \delta x$. Here, $D^{*}$ is the characteristic fire diameter, $\delta x$ is the nominal size of a mesh cell, and $\dot{Q}$ is the total heat release rate of the fire:

$$
D^{*}=\left(\frac{\dot{Q}}{\rho_{\infty} c_{p} T_{\infty} \sqrt{g}}\right)^{\frac{2}{5}}
$$


From the FDS User's Guide [8], the characteristic fire diameter is related to the characteristic fire size via the relation $Q^{*}=\left(D^{*} / D\right)^{5 / 2}$. Here, $D$ is the physical diameter of the base of the fire specified in the simulation. Following Eq. 3.2 and using a grid cell size of $10 \mathrm{~cm}(3.9 \mathrm{in})$, the characteristic fire diameter to cell size $\left(D^{*} / \delta x\right)$ ratio is 12 for the $1.8 \mathrm{MW}$ bathroom fire and 20 for the 6.75 MW basement fire. Based on validation work performed for the U.S. Nuclear Regulatory Commission, $D^{*} / \delta x$ values ranged between 4 and 16 [22] and produced results that were adequate for engineering calculations. The grid resolution used in this model is within or exceeds typical engineering $D^{*} / \delta x$ values.

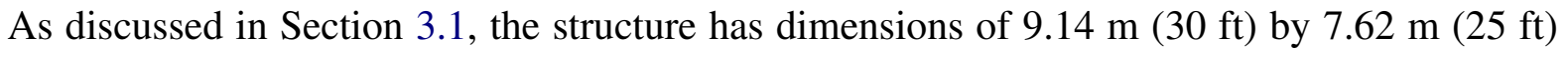
and a total height of $7.31 \mathrm{~m}(24 \mathrm{ft})$. To sufficiently resolve the wind boundary condition, the computational domain was extended beyond the volume of the structure. The large domain led to the use of two separate grid resolutions, a $10 \mathrm{~cm}$ (3.9 in) resolution and a $20 \mathrm{~cm}$ (7.8 in) resolution.

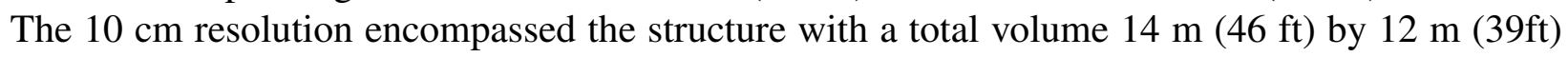
by $8 \mathrm{~m}(26 \mathrm{ft})$ that required a total of 1.3 million computational cells. As a result, all of the input model geometry lengths, ventilation openings (holes, doors, and windows), and fire areas will snap to the nearest $10 \mathrm{~cm}$. The $20 \mathrm{~cm}$ grid resolution extended the computational domain $5 \mathrm{~m}$ to the left and right sides and $4 \mathrm{~m}$ behind the $10 \mathrm{~cm}$ mesh to provide sufficient computational domain for the wind profile to develop around the structure. The mesh is coarser to cut down on computational time and because high accuracy in the fluid mechanics of the air flow far from the structure is not important in the analysis of this simulation. The $20 \mathrm{~cm}$ resolution resulted in an additional 216000 computational cells.

Figure 3.6 shows the front and rear of the structure and surrounding domain rendered in Smokeview with the $10 \mathrm{~cm}$ and $20 \mathrm{~cm}$ meshes. Note the finer mesh (smaller cells) surrounding the structure and the coarser mesh on each side. The domain was divided into 12 equally sized $10 \mathrm{~cm}$ meshes that surrounded the structure (each containing 150000 grid cells) plus 4 equally sized $20 \mathrm{~cm}$ meshes to the left and right of the structure (each containing 32000 grid cells) and one $20 \mathrm{~cm}$ mesh in the rear of the structure (containing 56000 grid cells) for a total of 17 meshes. Multiple meshes allowed the simulation to be processed in parallel, which reduced the amount of required calculation time to approximately 3 days from over 1 week with a uniform $10 \mathrm{~cm}$ mesh. Figure 3.7 shows the entire structure within the computational domain that has been divided into multiple meshes. The boundary between the twelve $10 \mathrm{~cm}$ meshes and five $20 \mathrm{~cm}$ meshes is indicated by the bold lines. 

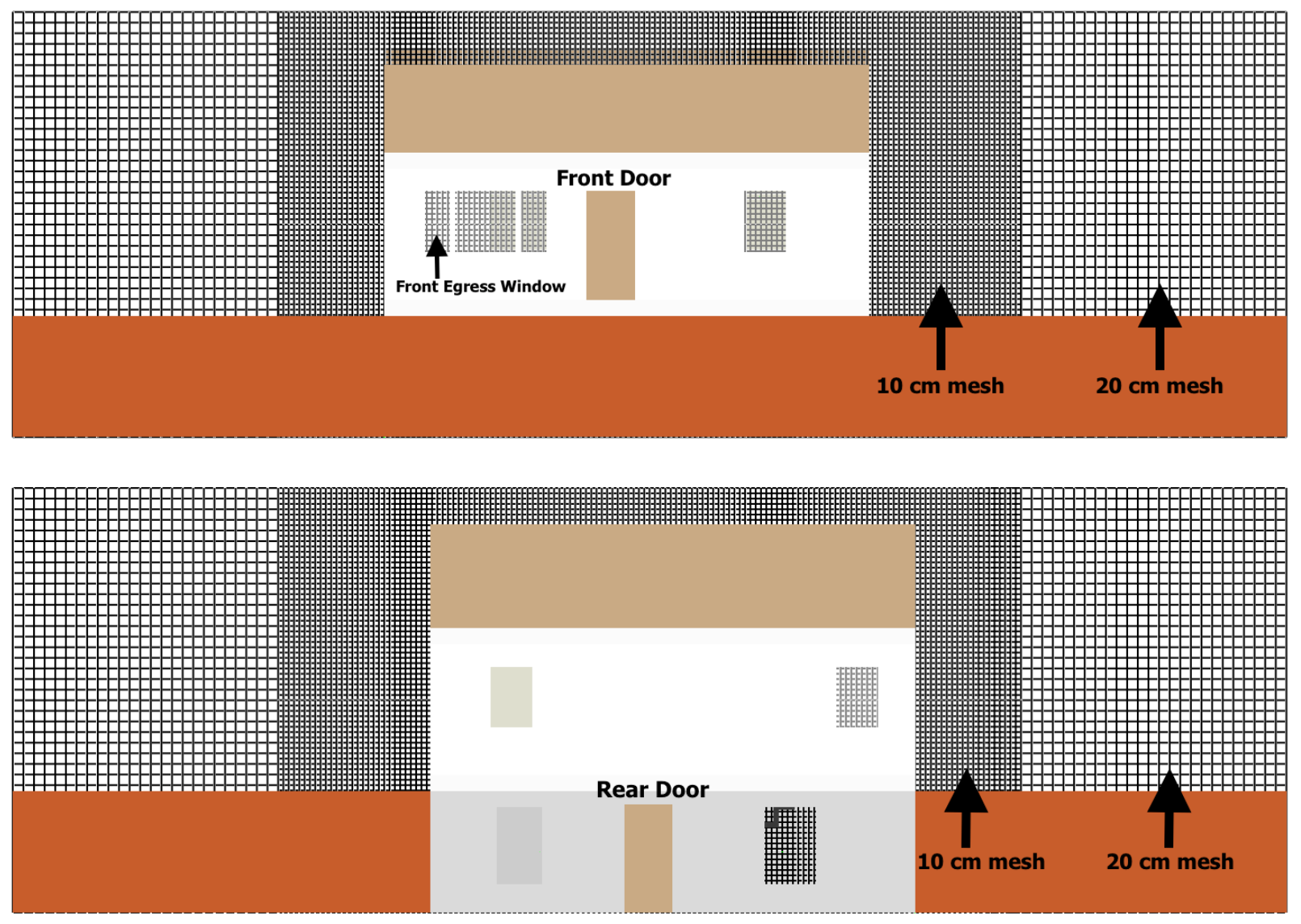

Figure 3.6: Front (top) and rear (bottom) of the structure with $10 \mathrm{~cm}$ computational mesh surrounding the structure and $20 \mathrm{~cm}$ mesh to the left and right of the structure. 


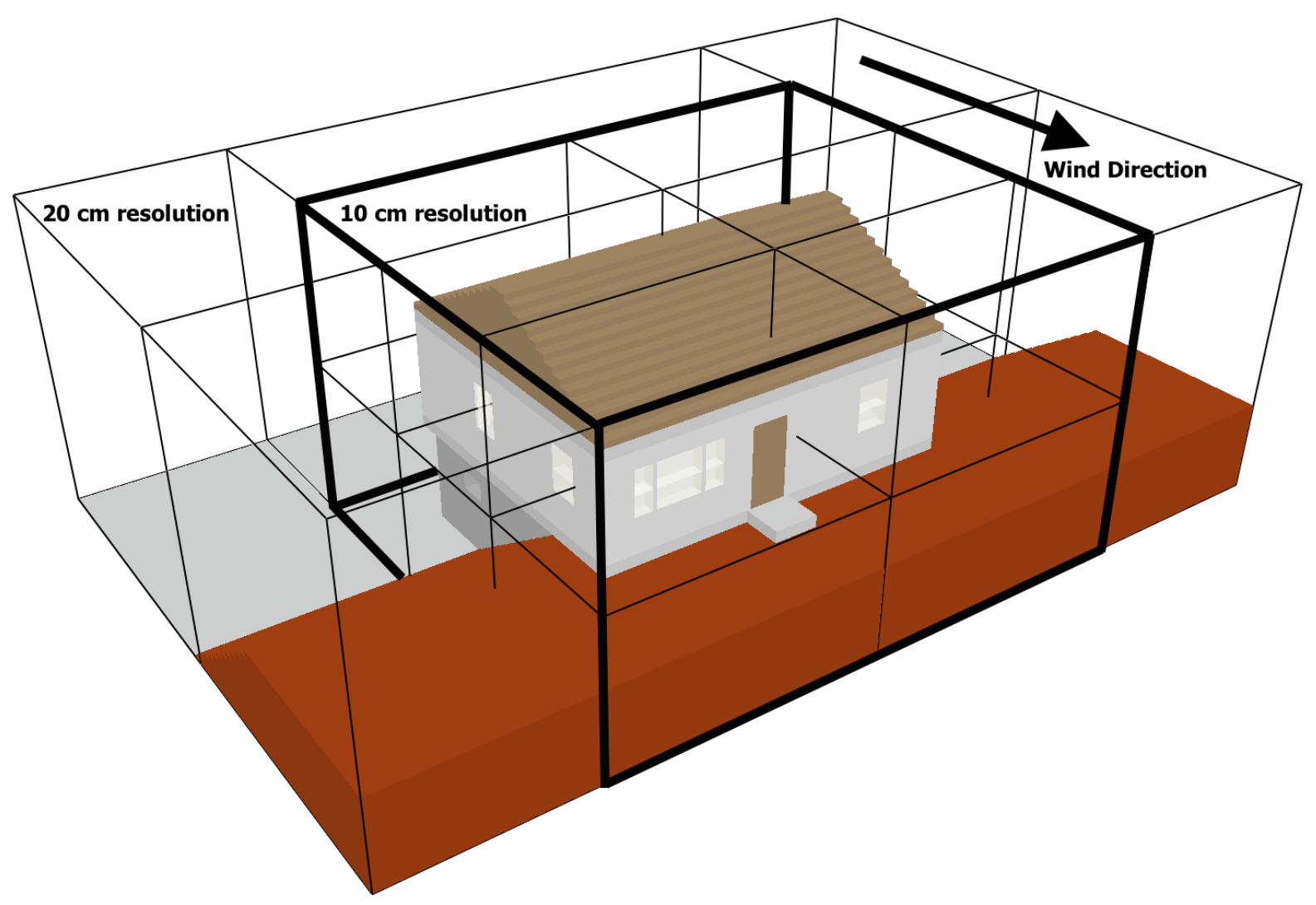

Figure 3.7: Overhead front-left view of the structure within the computational domain (with 17 meshes). The entire computational domain was $24 \mathrm{~m}(79 \mathrm{ft})$ by $16 \mathrm{~m}(53 \mathrm{ft})$ by $8 \mathrm{~m}(26 \mathrm{ft})$. 


\subsection{Summary of Model Input Parameters}

Table 3.2 shows a summary of the model input parameters for the simulation that was conducted as part of this study. In reality, the quantities associated with model input parameters are not fixed values; rather, a model input parameter can be thought of as a point estimate from a distribution of possible input parameters with some associated amount of uncertainty. Any change in an input parameter (such as the HRR) for a given scenario results in a change in the output quantity (such as the hot gas layer (HGL) temperature).

For example, according to the McCaffrey, Quintiere, and Harkleroad [23] empirical correlation, the HGL temperature in a well-ventilated compartment fire is proportional to the HRR raised to the two-thirds power. Following this relationship, a $7.5 \%$ increase in the HRR would result in a $5 \%$ increase in the HGL temperature [24]. More detailed discussion on the propagation of parameter uncertainty in fire models is available in a validation study that was sponsored by the U.S. Nuclear Regulatory Commission [24].

Table 3.2: Relevant fire model input parameters.

\begin{tabular}{|c|c|c|}
\hline Parameter & Description & Discussion \\
\hline Simulation Time & $5 \mathrm{~min}$ & - \\
\hline Grid Cell Size & $\begin{array}{l}10 \mathrm{~cm} \text { around house } \\
20 \mathrm{~cm} \text { for wind }\end{array}$ & Section 3.5 \\
\hline Ambient Temperature* & $20{ }^{\circ} \mathrm{C}\left(68^{\circ} \mathrm{F}\right)$ & - \\
\hline Reaction: Wood [14] & $\begin{array}{l}\text { Formula: } \mathrm{CH}_{1.7} \mathrm{O}_{0.74} \mathrm{~N}_{0.002} \\
\text { CO Yield: } 0.004 \mathrm{~kg} / \mathrm{kg} \\
\text { Soot Yield: } 0.015 \mathrm{~kg} / \mathrm{kg} \\
\text { Heat of Combustion: } 16,400 \mathrm{~kJ} / \mathrm{kg}\end{array}$ & Section 3.2 \\
\hline Peak HRR & $\begin{array}{l}\text { Basement Fire: } 6.75 \mathrm{MW} \\
\text { Bathroom Fire: } 1.8 \mathrm{MW}\end{array}$ & Section 3.2 \\
\hline Material: Wood [20] & $\begin{array}{l}k: 0.12 \mathrm{~W} /(\mathrm{m} \cdot \mathrm{K})) \\
\rho: 510 \mathrm{~kg} / \mathrm{m}^{3} \\
c_{p}: 1.38 \mathrm{~kJ} /(\mathrm{kg} \cdot \mathrm{K})\end{array}$ & Section 3.3 \\
\hline Material: Gypsum Board [19] & $\begin{array}{l}k: 0.28 \mathrm{~W} /(\mathrm{m} \cdot \mathrm{K}) \\
\rho: 810 \mathrm{~kg} / \mathrm{m}^{3} \\
c_{p}: 1.0 \mathrm{~kJ} /(\mathrm{kg} \cdot \mathrm{K})\end{array}$ & Section 3.3 \\
\hline Wind & $8.9 \mathrm{~m} / \mathrm{s}(20 \mathrm{mph})$ & Section 3.4 \\
\hline
\end{tabular}




\section{Section 4}

\section{Model Results}

To examine the results of the simulation, it is important to link the timelines from the fire scene to the simulation times. Table 4.1 shows the fireground timeline [10] along with the corresponding simulation times. 
Table 4.1: Fire incident and simulation event timeline.

\begin{tabular}{|c|c|c|}
\hline $\begin{array}{l}\text { Incident Time } \\
\text { (hh:mm:ss) }\end{array}$ & $\begin{array}{l}\text { Simulation } \\
\text { Time } \\
\text { (s) }\end{array}$ & Fire Behavior / Fireground Operation \\
\hline 21:08:26 & & First 911 call is made. \\
\hline 21:11:03 & & $\begin{array}{l}\text { Dispatch for a"box" alarm assignment- four engine companies } \\
\text { two truck companies, one rescue squad, and a commanding officer. }\end{array}$ \\
\hline $21: 21: 20$ & 0 & FDS simulation begins. \\
\hline $21: 12: 55$ & & First unit (Engine 807B) arrived on-scene. \\
\hline $21: 13: 44$ & & Volunteer Chief 809A establishes incident command (IC). \\
\hline $21: 13: 56$ & & Truck 809 arrived on-scene. \\
\hline $21: 14: 00$ & 100 & Front door opened. \\
\hline $21: 14: 42$ & & Truck 809 enters structure. \\
\hline $21: 15: 47$ & 207 & $\begin{array}{l}\text { Front door closed over. } \\
\text { Basement door opened and water applied to fire. }\end{array}$ \\
\hline $21: 15: 51$ & 211 & Lower pane of front egress window broken. \\
\hline 21:16:01 & 221 & Top pane of front egress window broken. \\
\hline $21: 16: 16$ & & Truck 809 officer bailout through front window. \\
\hline $21: 16: 47$ & 267 & Front door opened. \\
\hline $21: 17: 15$ & & Truck 809 forcible entry firefighter rescued. \\
\hline
\end{tabular}




\subsection{Heat Release Rate}

In FDS, a HRR must be specified, which results in a specified amount of fuel vapor (or pyrolyzate) being released from a fuel surface. FDS then determines the amount of combustion that occurs throughout the simulation based on the amount of available fuel and oxygen at a given location. As a result, the prescribed HRR that was input into the simulation can be different than the HRR calculated by FDS based on the ventilation conditions.

Figure 4.1 shows the HRR in the structure vs. time based on the fires described in Section 3.2. In this figure, the solid line represents the prescribed HRR that was input into the simulation (based on a prescribed mass flux), and the dashed line represents the HRR inside the structure that was calculated by FDS based on the ventilation conditions. The vertical lines represent the times at which ventilation occurred: front door opening and closing as well as the breaking of a front window for emergency escape. See Table 3.1 for a detailed list of the ventilation that occurred during the incident. The maximum size of the fire specified in this study was selected such that the conditions aligned with observations and fuel loads from the actual fire incident.

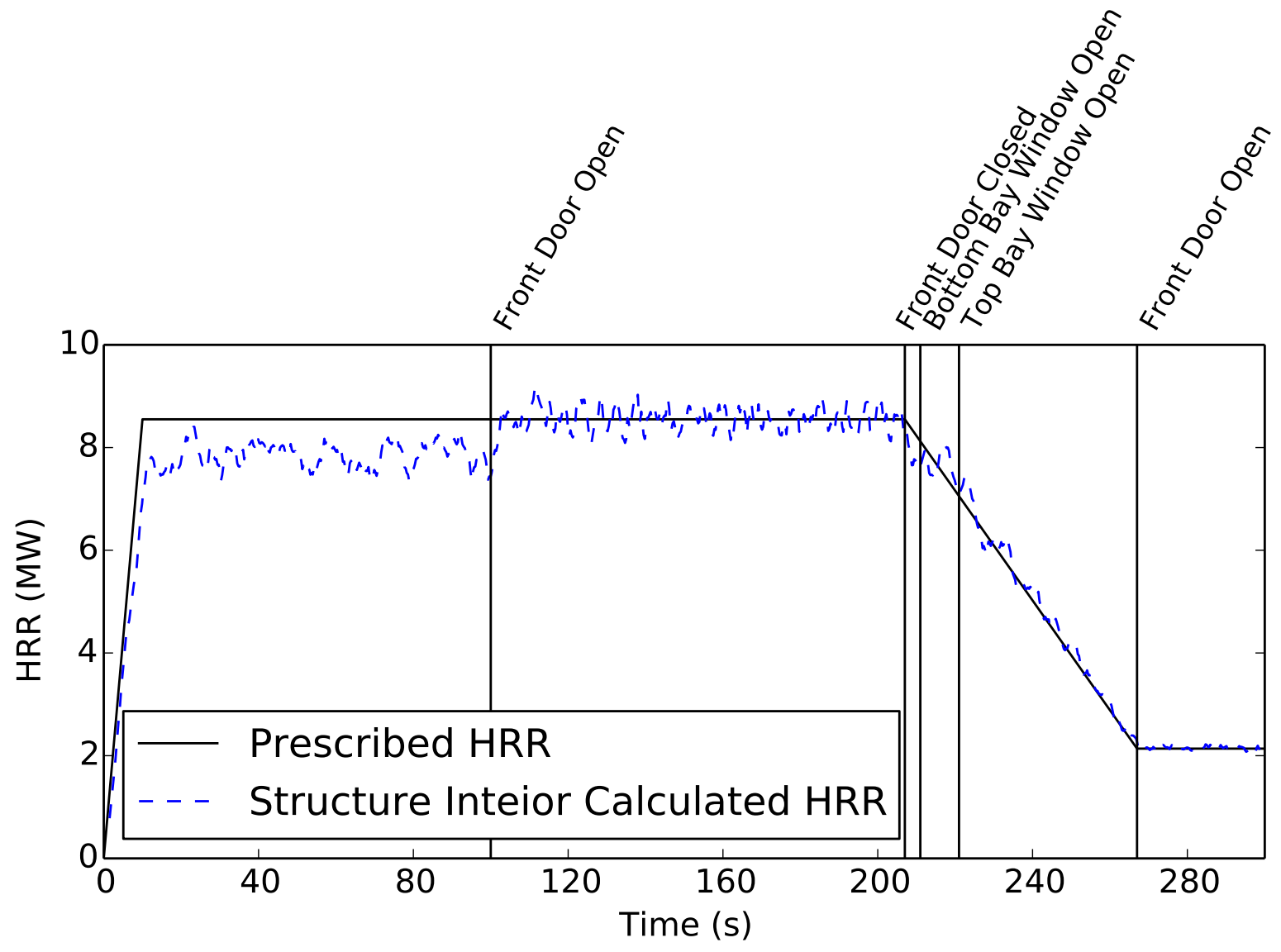

Figure 4.1: Comparison of prescribed and calculated interior HRRs from the FDS simulation. The vertical lines indicate the times when ventilation occurred. 
In Fig. 4.1, the prescribed HRR that was input into the simulation is different than the HRR calculated by FDS based on the ventilation conditions. From $0 \mathrm{~s}$ to approximately $9 \mathrm{~s}$, the calculated HRR was in approximate agreement with the prescribed HRR because there was an adequate amount of oxygen for all of the fuel to combust. The differences in prescribed versus predicted HRR is a result of either fuel accumulation within the structure not combusting because of a lack of oxygen or combustion occurring exterior to the structure where fuel and oxygen can mix and react. Fig. 4.2 shows the total calculated HRR within the computational domain (includes combustion occurring exterior to the structure) compared to the prescribed HRR curve.

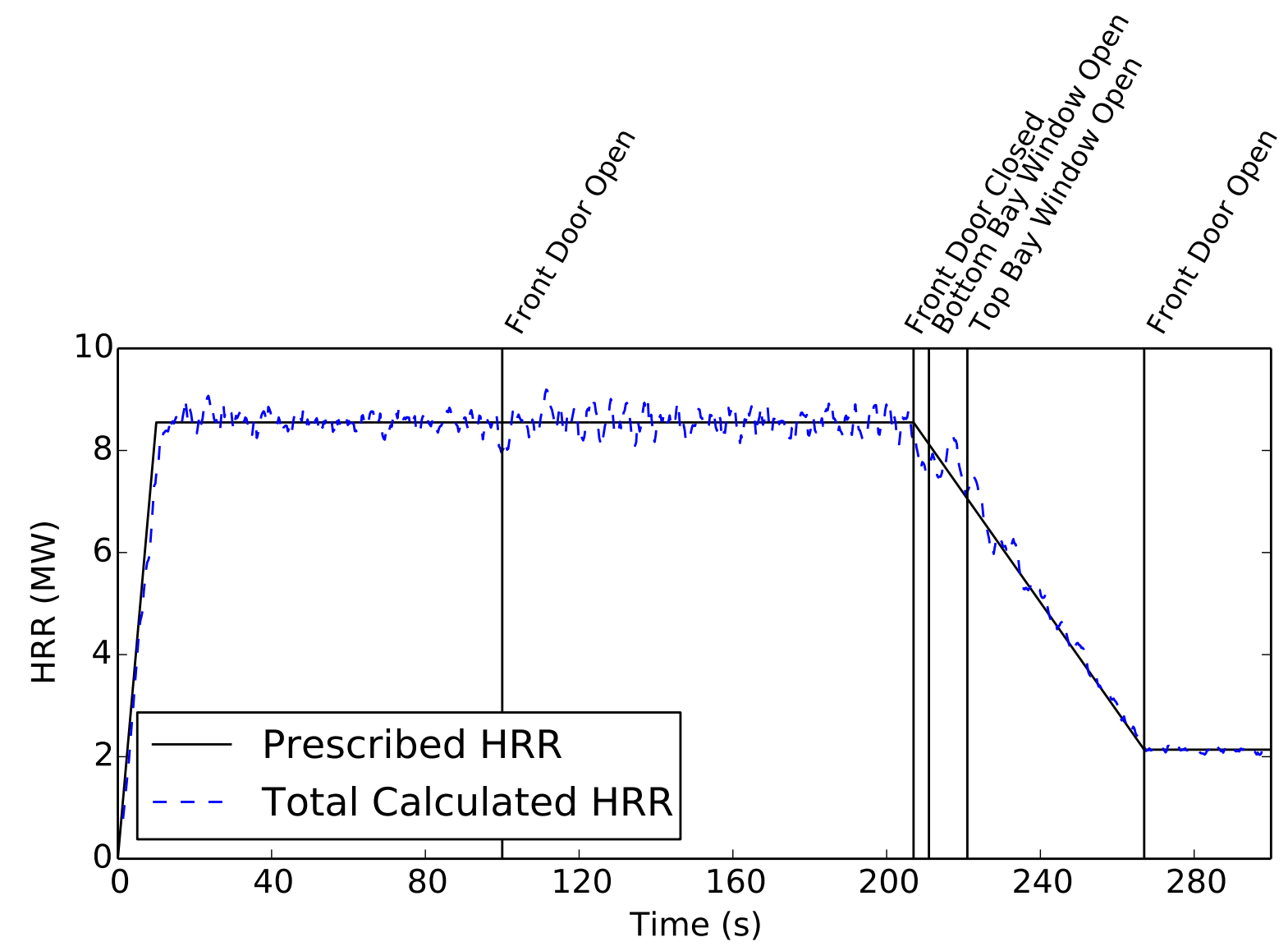

Figure 4.2: Comparison of total prescribed and calculated HRRs within the entire computational domain from the FDS simulation. The vertical lines indicate the times at which ventilation occurred.

A comparison of the differences between the HRR inside the structure (Fig. 4.1) and the total HRR (Fig. 4.2) over the first $100 \mathrm{~s}$ of the simulation indicated that on average there was the equivalent of an approximate $0.7 \mathrm{MW}$ fire(s) occurring through open external vents (basement windows). This aligns with observed post-fire damage and post-incident report [10]. Fig. 4.3 shows a post-fire image of the back left corner of the structure as well as a Smokeview rendering of the fire from the FDS simulation prior to the front door being opened by firefighters. 

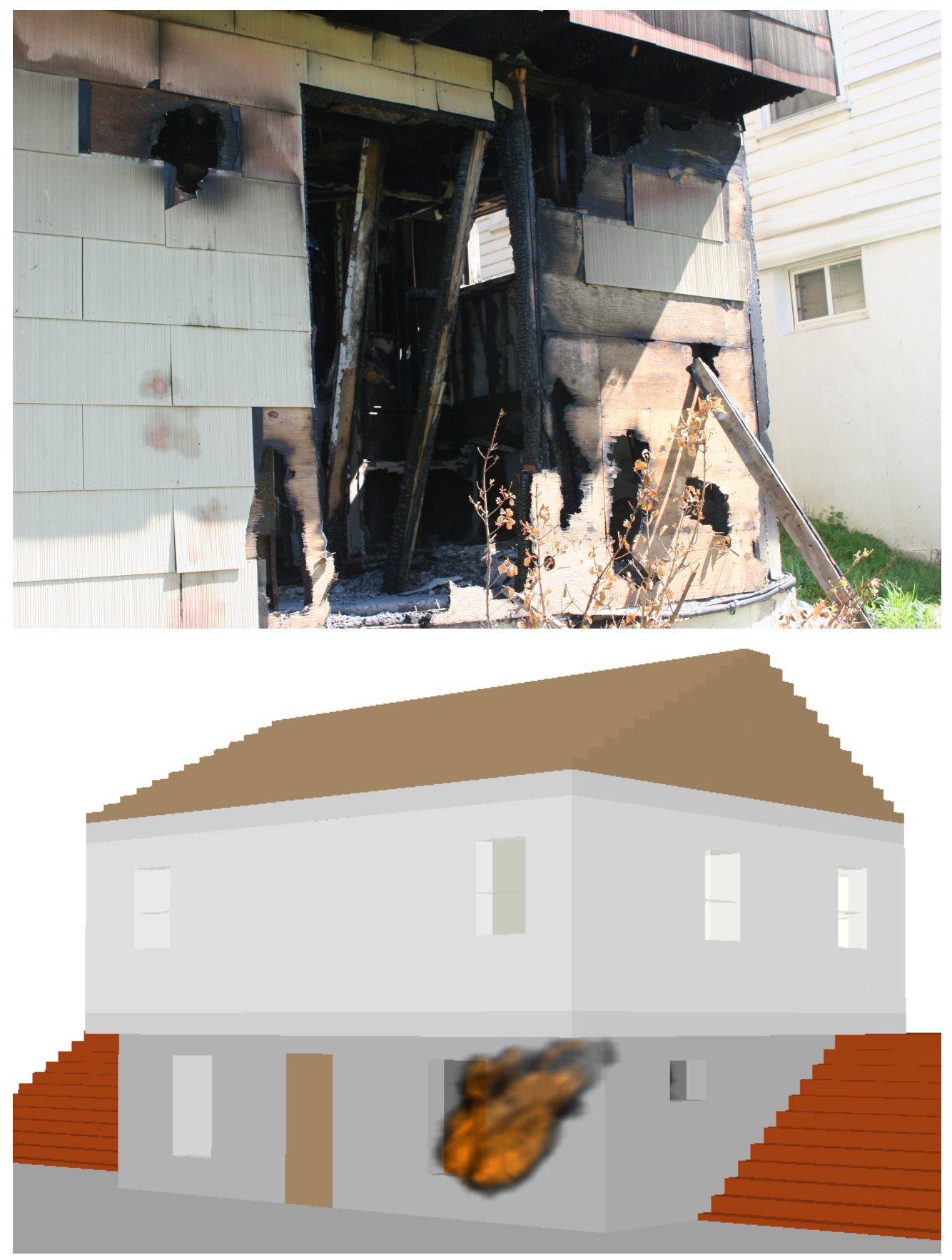

Figure 4.3: External post-fire image of damage to the basement (top) and FDS model showing external fire prior to the front door of the structure being opened (bottom).

After $100 \mathrm{~s}$ of simulation time, $5.5 \mathrm{~min}$ after the first 911 call, firefighters open the front door to make entry to the first floor of the structure. The change in ventilation to the structure impacted the HRR. After the door was opened combustion no longer took place outside of the structure, as shown in Fig. 4.4, however the basement HRR was lower than the total HRR within the domain.

The differences in HRR between the total HRR and the basement HRR can be accounted for 


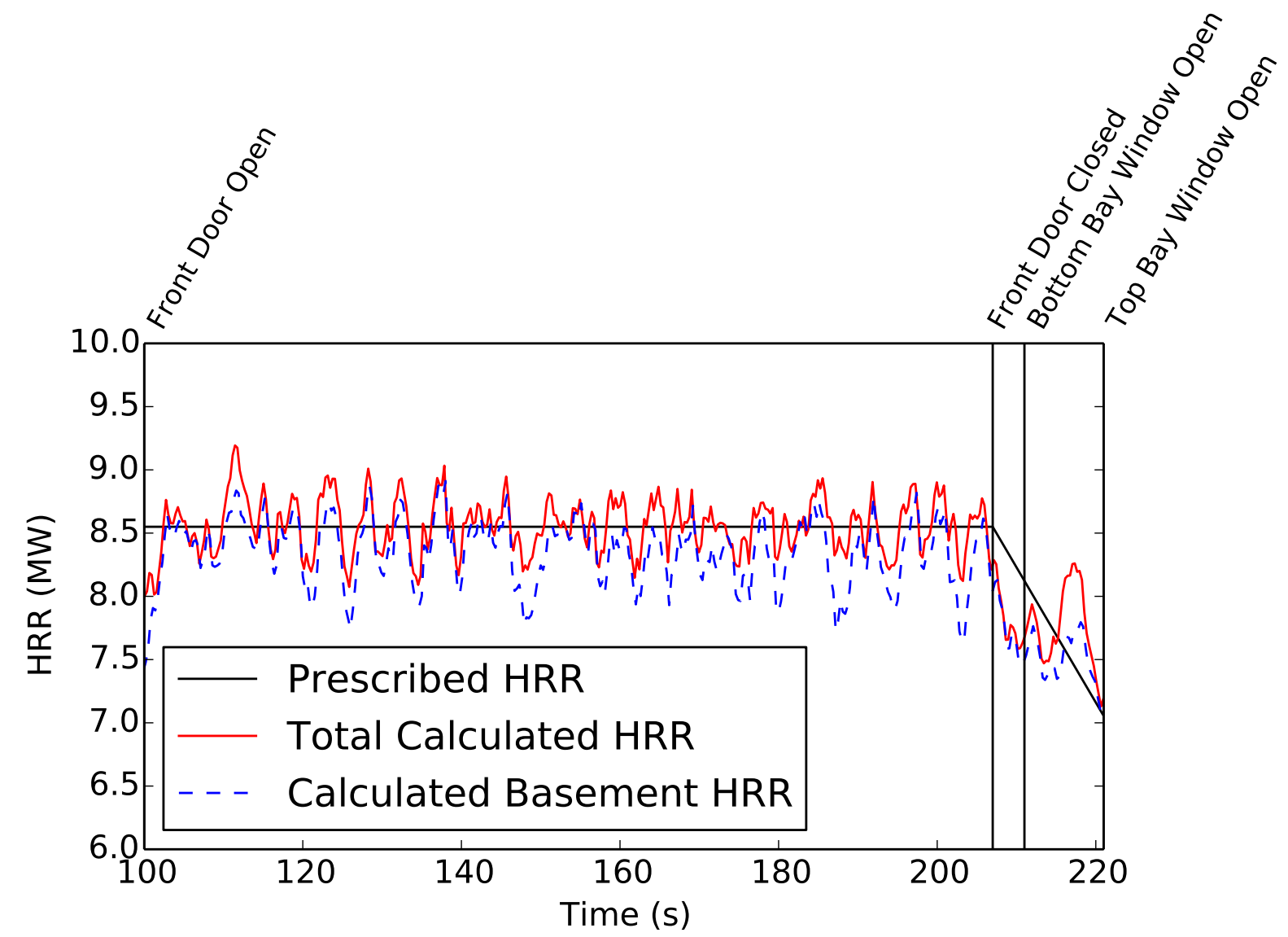

Figure 4.4: Comparison of prescribed, total calculated domain HRR and basement calculated HRRs from the simulation. The vertical lines indicate the times when ventilation changed.

in combustion occurring on the first floor of the structure. Fuel that was combusting outside of the structure due to a lack of oxygen combusts on the first floor of the structure as the open front door allows flow to occur within the structure and fuel to mix with available oxygen and react (Fig. 4.5). 


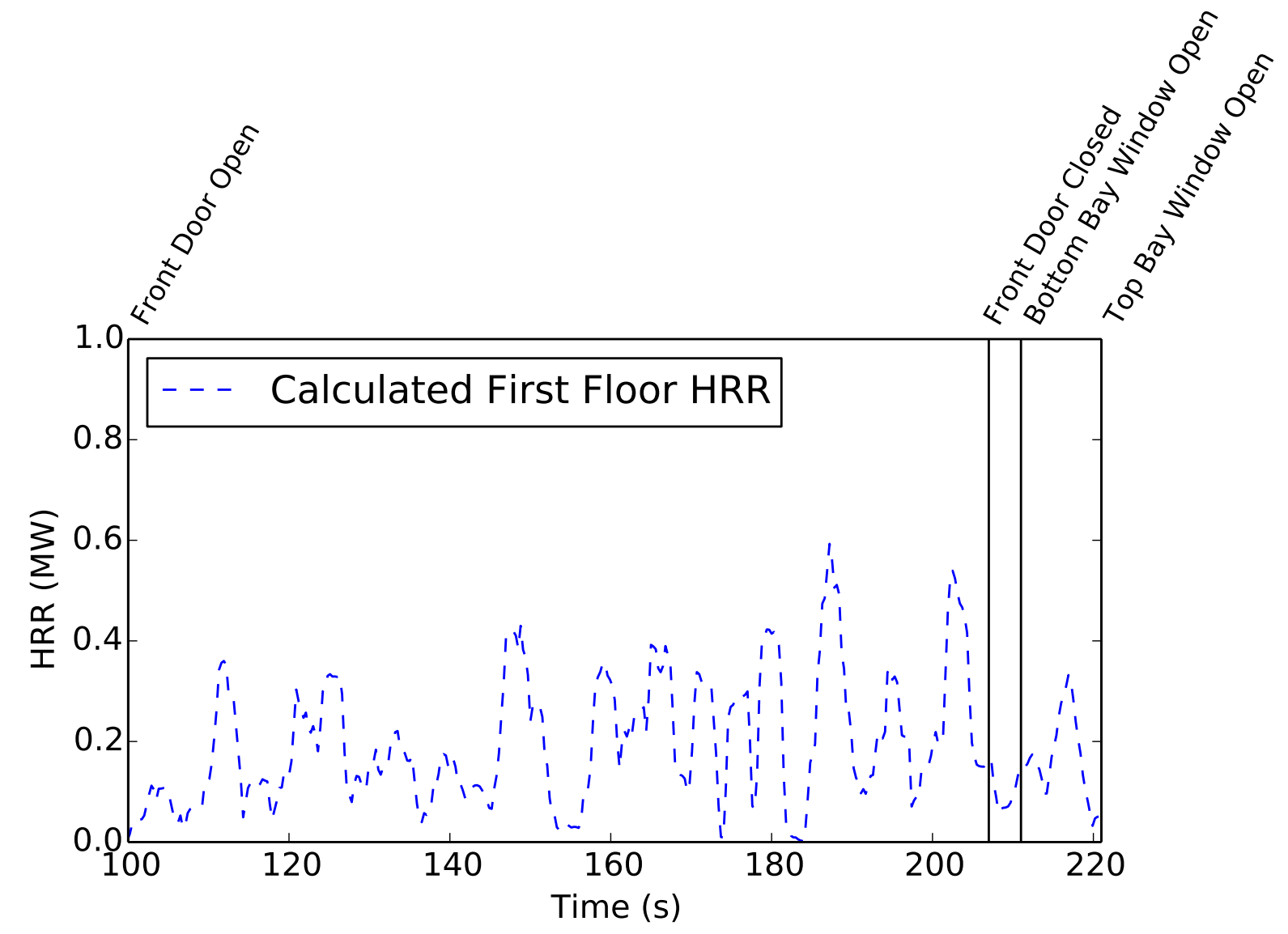

Figure 4.5: First floor calculated HRR from the simulation. The vertical lines indicate the times when ventilation changed. 


\subsection{Pressure}

The growth of the fire combined with a $8.9 \mathrm{~m} / \mathrm{s}(20 \mathrm{mph})$ wind flowing normal to the rear of the structure caused the pressure to rise within the structure. Hot gases which may have built up within the structure will flow from high pressure to low pressure. Based on the event timeline, the front door was opened $100 \mathrm{~s}$ into the simulation, which would create a low pressure relief on the first floor. Due to firefighters entering the structure through the front door, the simulated pressure on the first floor prior to and just after opening the door is important. Figure 4.6 shows the calculated pressure conditions in the structure just before and after the front door was opened (100 s) in the simulation.

In the top snapshot in Fig. 4.6, the pressure profile shows an overpressure of approximately $200 \mathrm{~Pa}\left(2.9 \times 10^{-2} \mathrm{psi}\right), 1 \mathrm{~s}$ prior to the door being opened. This pressure may be on the conservative side (over-prediction) because of wind speed fluctuations, wind direction, and small amounts of structure leakage. One second after the door was opened (bottom snapshot in Fig. 4.6), the pressure on the first floor drops to between $75 \mathrm{~Pa}\left(1.1 \times 10^{-2} \mathrm{psi}\right)$ and $85 \mathrm{~Pa}\left(1.2 \times 10^{-2} \mathrm{psi}\right)$. Without the presence of wind, the pressure in the first floor prior to the door opening was approximately $18 \mathrm{~Pa}\left(2.6 \times 10^{-3} \mathrm{psi}\right)$ and after the door was opened the pressure drops to between $5 \mathrm{~Pa}(7.3 \times$ $\left.10^{-4} \mathrm{psi}\right)$ and $10 \mathrm{~Pa}\left(1.4 \times 10^{-3} \mathrm{psi}\right)$. 

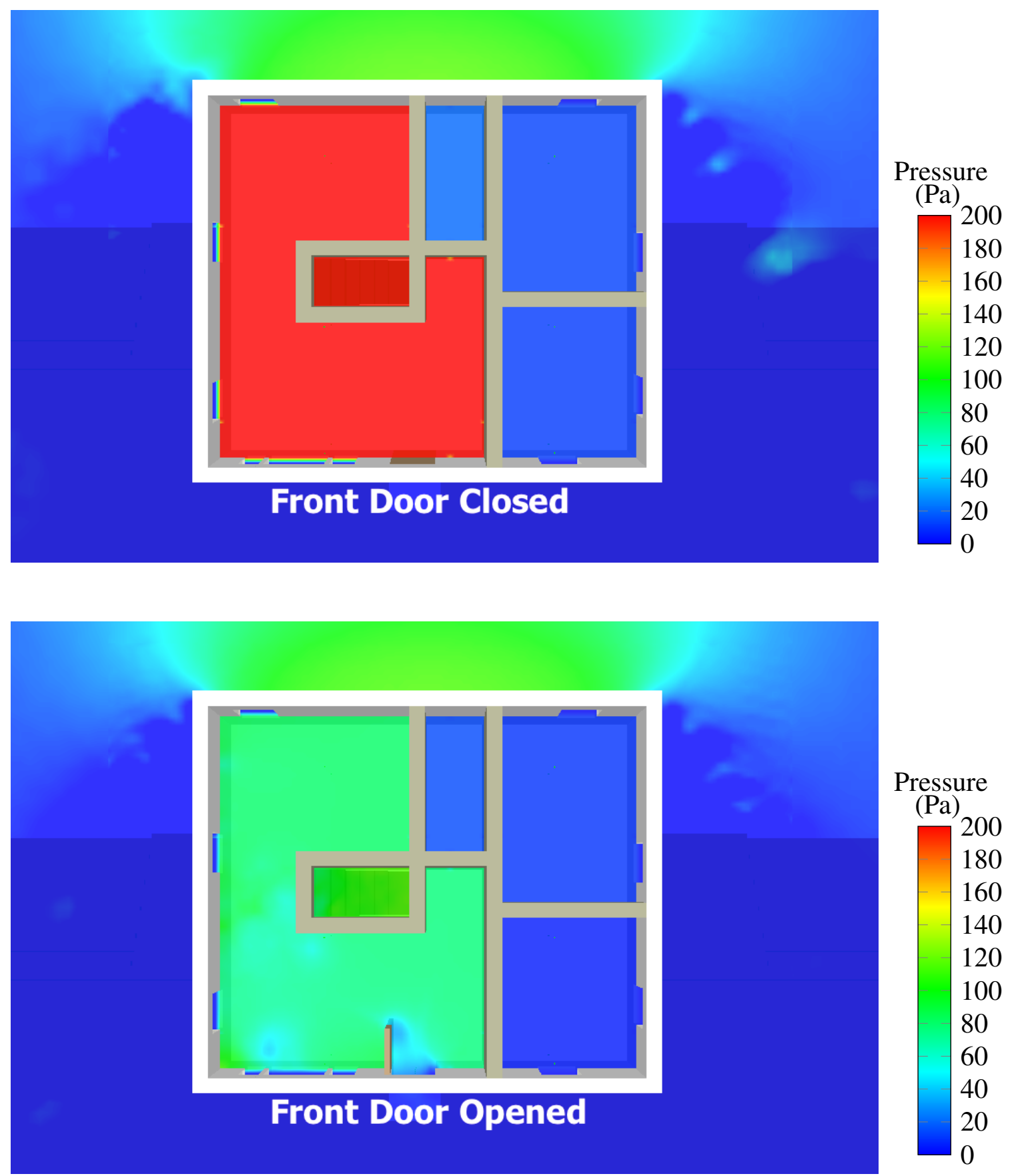

Figure 4.6: Calculated pressure contours on the first floor of the structure $1 \mathrm{~s}$ prior to (top) and $1 \mathrm{~s}$ after (bottom) firefighter entry through the front door at $0.91 \mathrm{~m}(3 \mathrm{ft})$ above the floor. 


\subsection{Velocity}

Gases flow from a region of high pressure towards a region of lower pressure. Once the front door opened, the gases in the basement at an elevated temperature and pressure flowed upward into the interior stairwell and exited the structure via the front door. The velocity contours shown in Fig. 4.7 indicate the magnitude of flow velocities within the structure before and after the front door was opened.

In Fig. 4.7, the velocity profile within the high-hazard area (first floor) is shown via two snap-

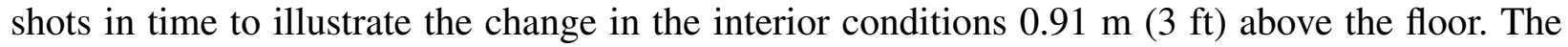
first snapshot is shown at a simulation time of $99 \mathrm{~s}$, which is $1 \mathrm{~s}$ before the front door was opened, and the second snapshot is shown at a simulation time of $101 \mathrm{~s}$, which is $1 \mathrm{~s}$ after the front door was opened. The velocity contours shown indicate that prior to the front door being opened, there was minimal flow on the first floor. However, after the front door was opened, a flow path was established forcing the combustion products from the basement fire to flow to the first floor through the interior stairwell. The simulation calculated the flow exiting the structure to be approximately $11 \mathrm{~m} / \mathrm{s}(25 \mathrm{mph})$. 

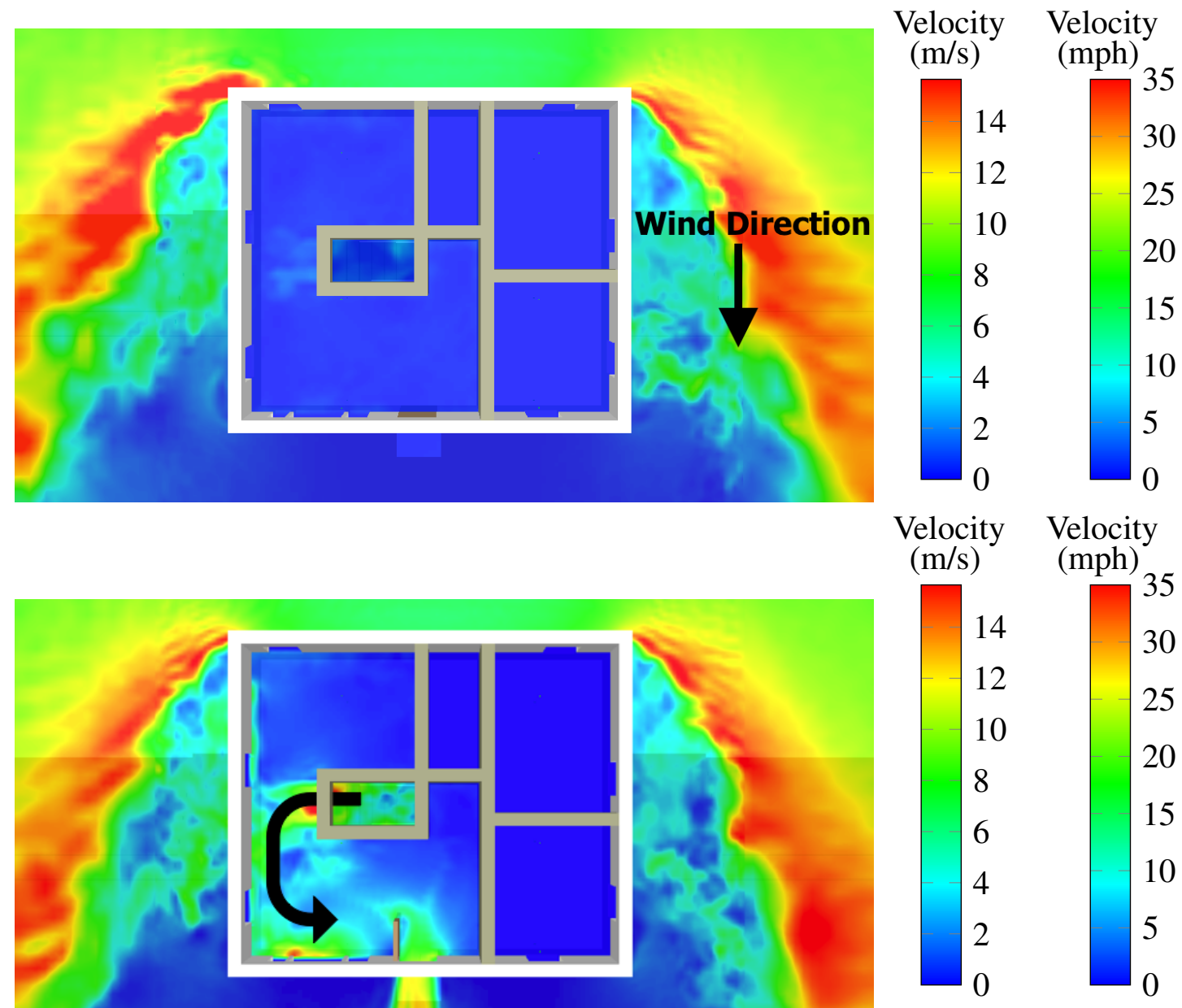

Figure 4.7: Calculated velocity contours on the first floor of the structure $1 \mathrm{~s}$ prior to (top) and $1 \mathrm{~s}$ after (bottom) firefighter entry through front door $0.91 \mathrm{~m}(3 \mathrm{ft})$ above the floor. Arrows indicate direction. 


\subsection{Temperature}

Analysis of the temperatures from the simulation focused on the high-hazard area of the structure: the first floor area between the front door and the top of the interior stairwell. The temperature contours shown in Fig. 4.8 indicate the gas temperatures within the structure $1 \mathrm{~s}$ before the front door

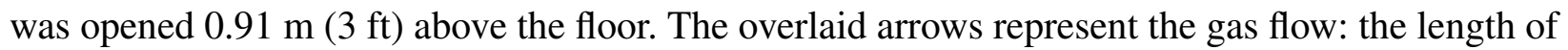
the lines represents the magnitude of the speed and the direction of the arrow represents the flow direction. Prior to the door opening, the open living area and kitchen on the first floor were approximately $60{ }^{\circ} \mathrm{C}\left(140{ }^{\circ} \mathrm{F}\right)$, while the peak temperatures were concentrated near the interior stairwell, $105^{\circ} \mathrm{C}\left(220^{\circ} \mathrm{F}\right)$. Note that there was very minimal flow throughout the first floor. Figures 4.9 and

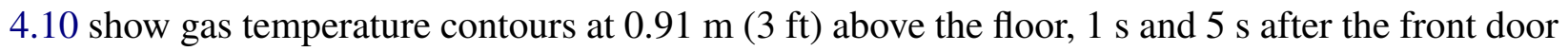
was opened.
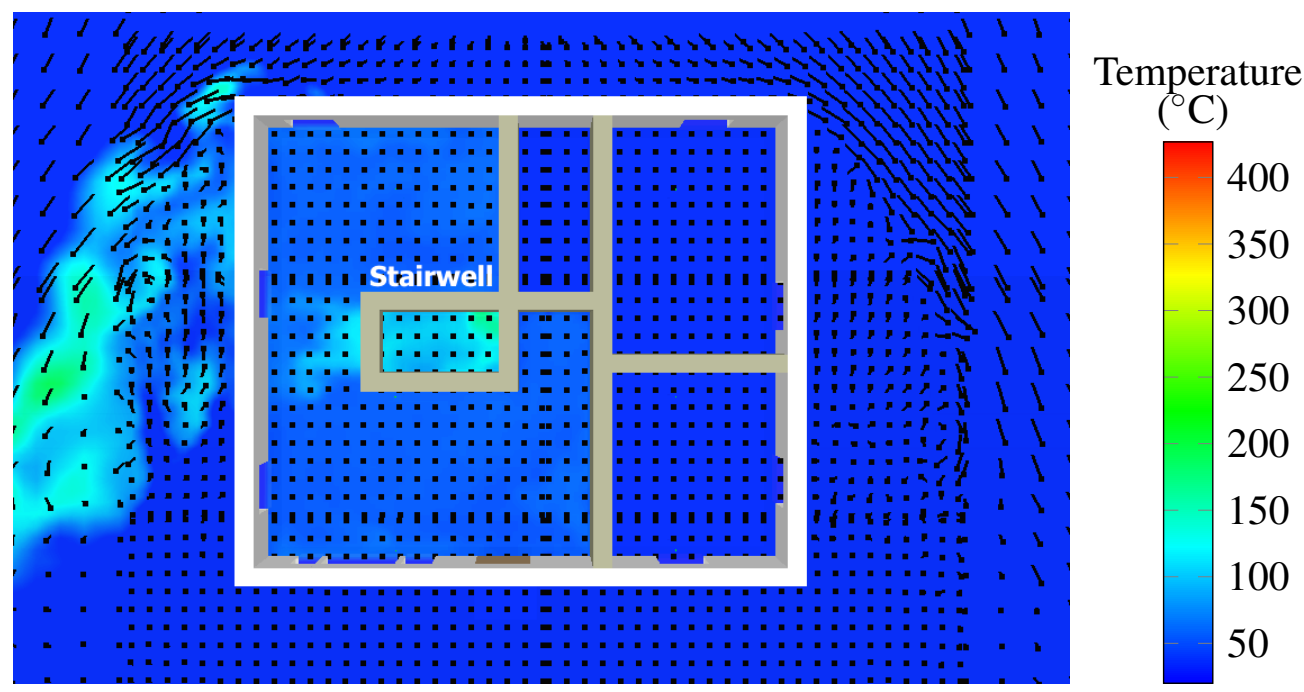

Temperature

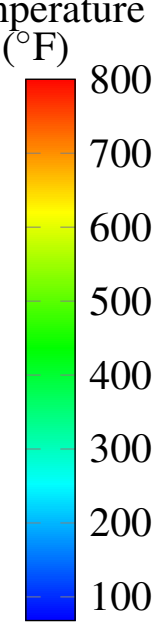

Figure 4.8: Calculated temperature contours on the first floor of the structure $1 \mathrm{~s}$ prior to firefighter entry through front door $0.91 \mathrm{~m}(3 \mathrm{ft})$ above the floor.

After the front door is opened, hot fire gases from the basement begin to flow through the interior stairwell into the first floor. Figure 4.9, $1 \mathrm{~s}$ after the front door was opened, shows that the temperature contours at the top of the stairwell have increased to approximately $200{ }^{\circ} \mathrm{C}\left(392{ }^{\circ} \mathrm{F}\right)$ with a hot spot that approached $425^{\circ} \mathrm{C}\left(800^{\circ} \mathrm{F}\right)$. Figure $4.10,5 \mathrm{~s}$ after the front door was opened, shows more significant increases in temperature. The area of at the top of the stairs is between $375^{\circ} \mathrm{C}\left(700^{\circ} \mathrm{F}\right)$ and $425^{\circ} \mathrm{C}\left(800^{\circ} \mathrm{F}\right)$. The gas temperatures $0.91 \mathrm{~m}(3 \mathrm{ft})$ above the floor at the front door have also increased to approximately $230{ }^{\circ} \mathrm{C}\left(450^{\circ} \mathrm{F}\right)$ and show increased flow velocities. 


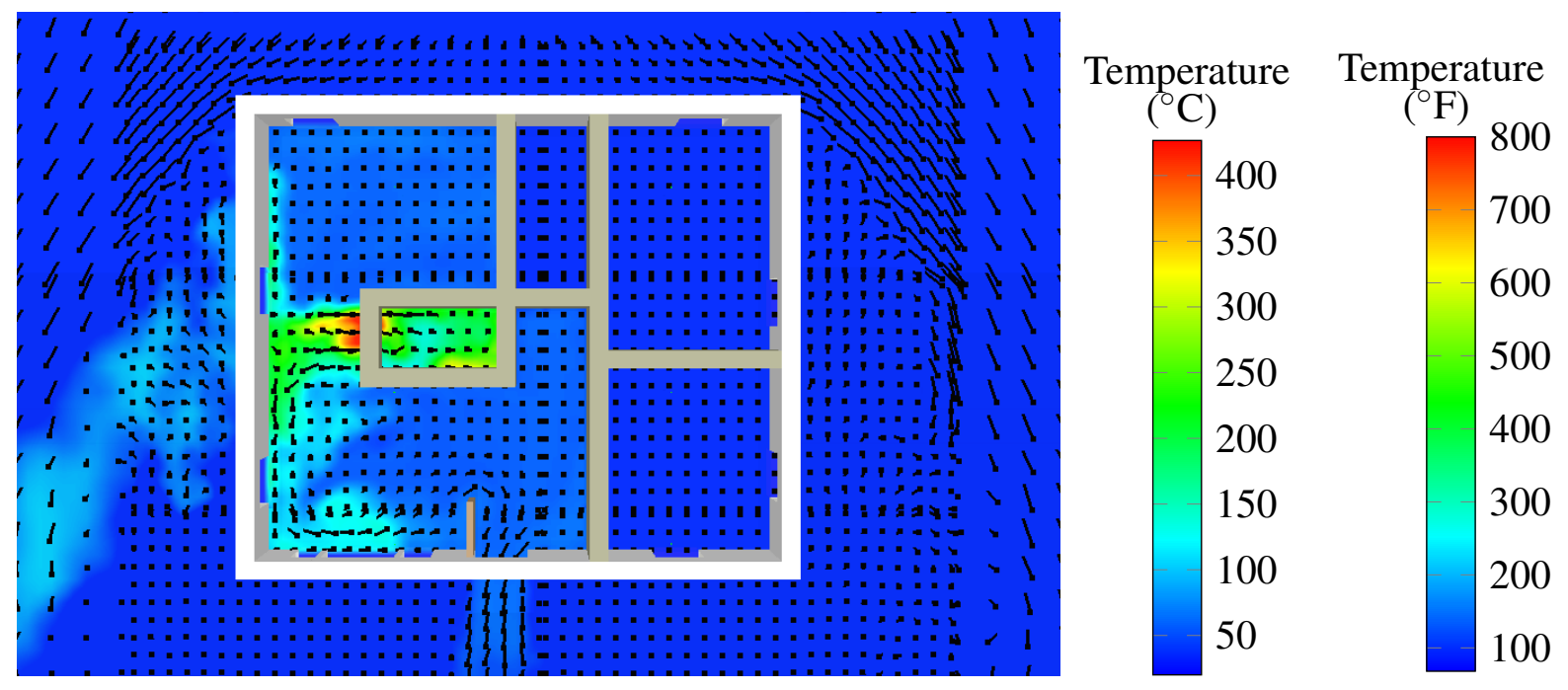

Figure 4.9: Calculated temperature contours on the first floor of the structure $1 \mathrm{~s}$ after firefighter

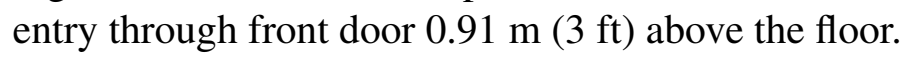
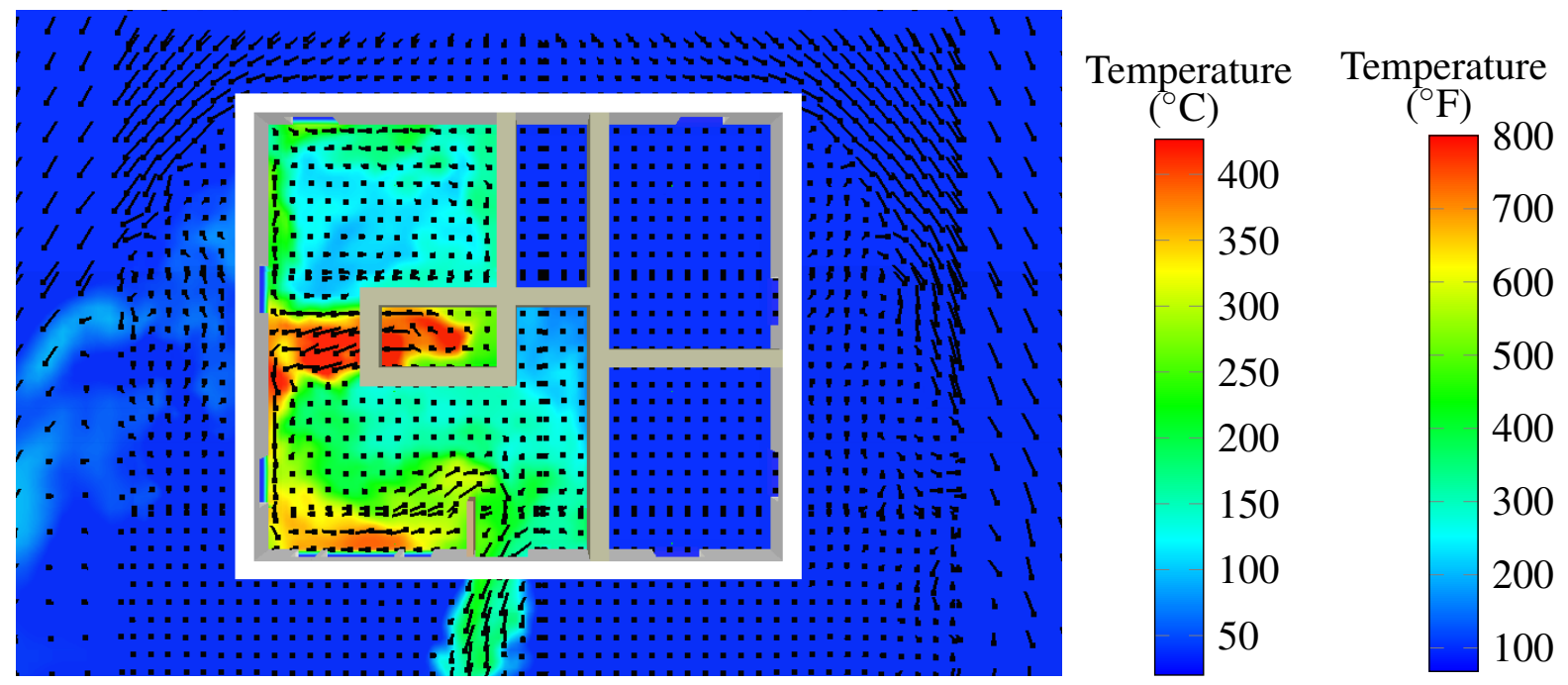

Figure 4.10: Calculated temperature contours on first floor of the structure $5 \mathrm{~s}$ after firefighter entry

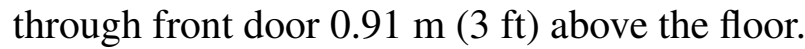




\section{Section 5}

\section{Discussion}

The results of the simulation are discussed in the following sections. Section 5.1 addresses the results of the simulation as they relate to the flow path that was established in the interior stairwell through the front door. Section 5.2 examines the model results as they relate to the hazardous conditions and exposure temperatures on the first floor. Section 5.3 discusses tactical considerations and outcomes of the fire incident as they relate to the fire dynamics and flow path conditions that have been observed in recent anaylses, modeling, and full and bench-scale experimental research.

\subsection{Simulated Flow Path}

The incident report from Prince George's County Fire/EMS [10] indicated that two firefighters from Truck 809 were seriosuly injured after making entry to the first floor. The interior conditions forced one firefighter to bail out through a first floor window on the front side of the structure and the other firefighter to be rescued through the front door. From Section 4.4, the conditions on the first floor were initially tenable. After the front door was opened, however, the simulation results indicated that a high hazard area existed in the first floor that exceeded the conditions that would put a firefighter at risk for burn injuries (temperatures greater than $260^{\circ} \mathrm{C}$ or $500{ }^{\circ} \mathrm{F}$ ) [25].

The simulation results indicate that a flow path was established between the open vents (windows) on the rear side of the basement and front side of the structure (through the front door of the first floor) after the front door was opened. Strong winds $(8.9 \mathrm{~m} / \mathrm{s}(20 \mathrm{mph}))$ pushed air into the rear side of the basement through window failures and combined with buoyant combustion gases to pressurize the structure. Opening the front door provided a pressure relief; this resulted in a rapid change in the conditions within the structure and the establishment of a flow path. After the front door was opened, the combustion gases at elevated temperature and pressure in the basement flowed towards lower pressure regions outside of the structure on the leeward side (front of structure) via the interior stairwell. The two injured firefighters were located in the flow path on the first floor between the top of the interior stairwell and the front door.

To examine the impact of opening the front door on the establishment of a flow path, flow conditions were examined along the centerline of the interior stairwell doorway and through the centerline of front door. Figure 5.1 shows the flow vectors at the first floor stairwell doorway $1 \mathrm{~s}$ before the front door was opened. Note that the length and direction of the arrows indicate the magnitude and direction of the flow, respectively. The color of the arrows correspond to the 
values from the included temperature scales. Therefore, a short blue arrow represents slow moving, cool gas while a long red arrow represents fast moving, high temperature gas. Prior to the door opening, there was minimal flow through the first floor stairwell door and the temperature peak was approximately $125^{\circ} \mathrm{C}\left(257^{\circ} \mathrm{F}\right)$ as shown in Figure 5.1. One second after the door opened, Figure 5.2, there was noticeable flow through both the stairwell doorway and through the front door. Simulated temperatures at the stairwell increased to approximately $200{ }^{\circ} \mathrm{C}\left(392{ }^{\circ} \mathrm{F}\right)$ and temperatures through the doorway were approximately $100^{\circ} \mathrm{C}\left(21{ }^{\circ}{ }^{\circ} \mathrm{F}\right)$. These values are also shown in planar contours $1 \mathrm{~m}$ above the floor in Figs. 4.7 and 4.9 for velocity and temperature, respectively.

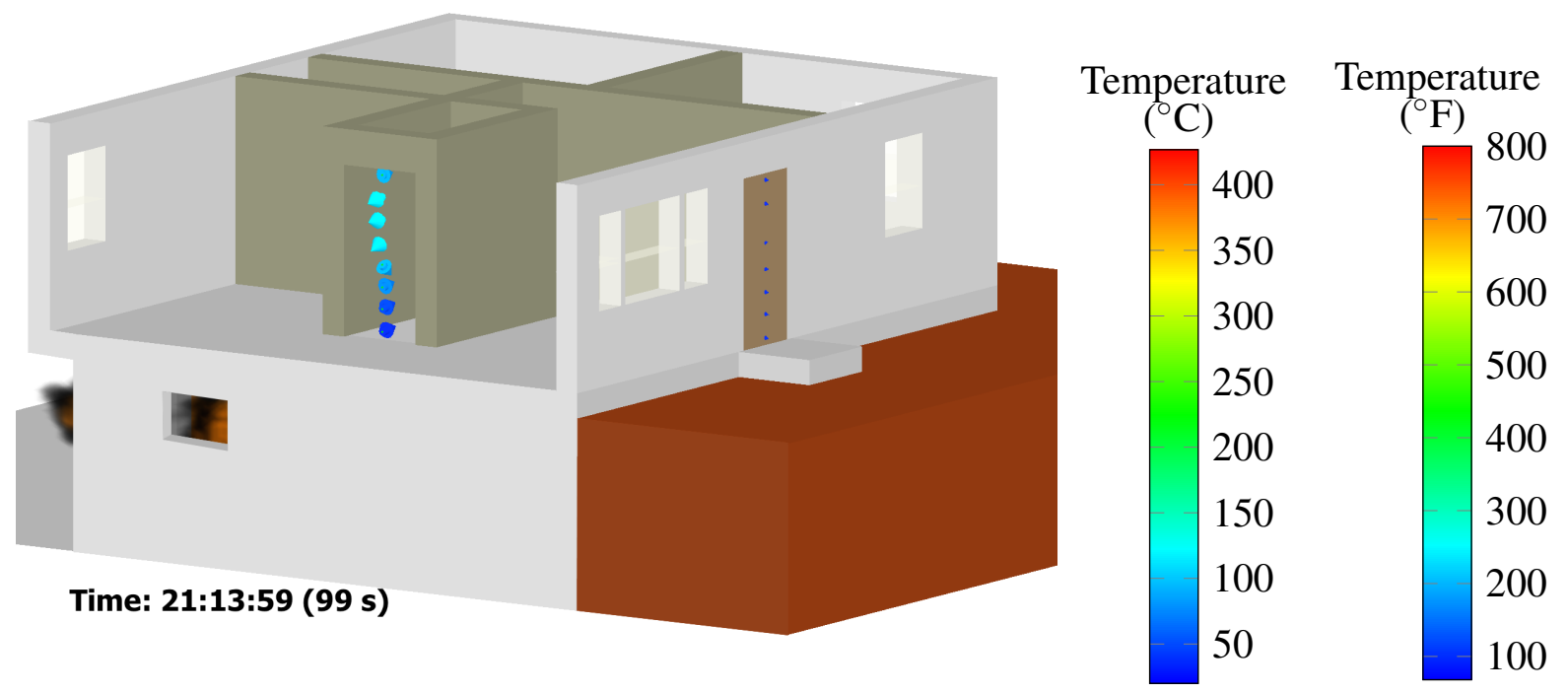

Figure 5.1: Flow path vectors at front door and top of stairwell $1 \mathrm{~s}$ before the front door was opened.

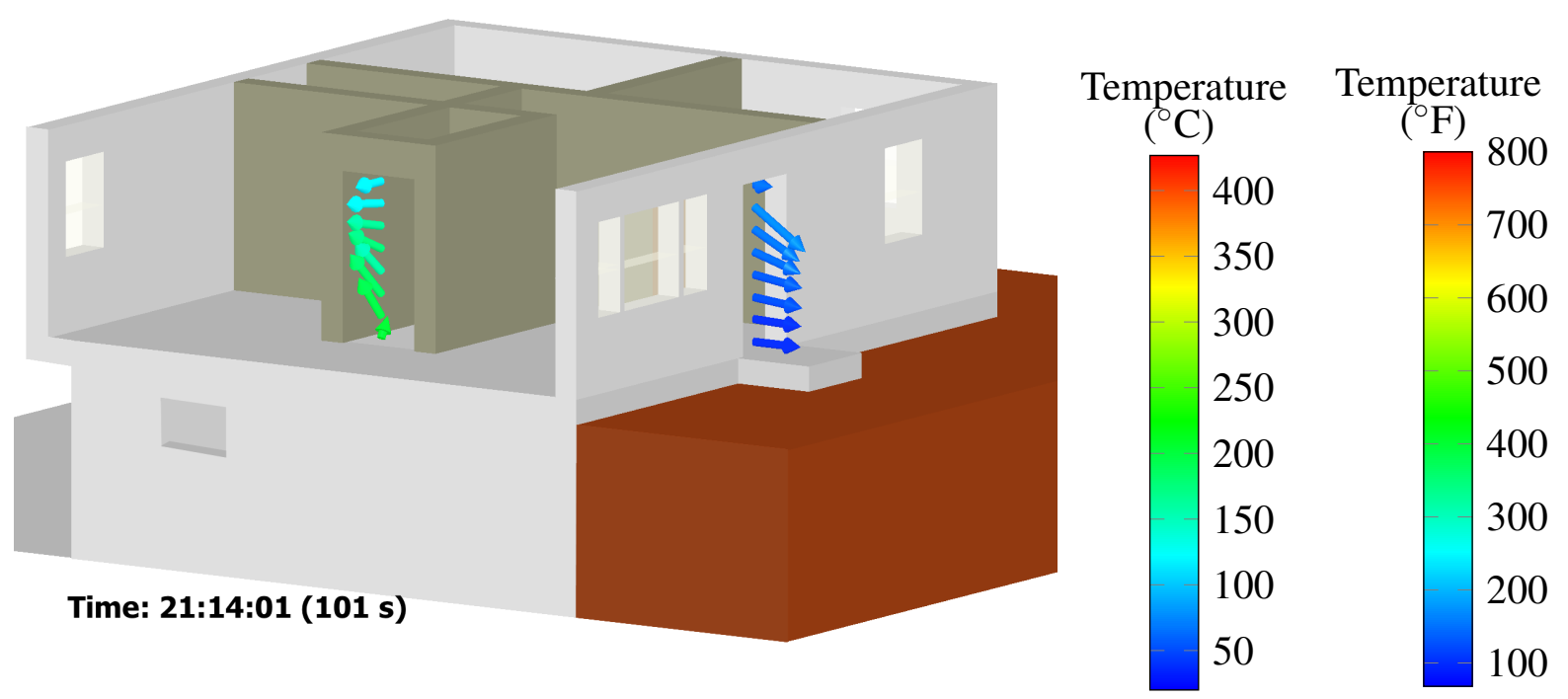

Figure 5.2: Flow path vectors at front door and top of stairwell $1 \mathrm{~s}$ after the front door was opened. 
At the estimated time of firefighter entry to the first floor (142 s into the simulation at 21:14:42; see Table 4.1), the simulated flow magnitudes through the first floor (stairwell and front doors) remained similar to the conditions just after opening the front door. Velocities through both the doorway at the top of the stairs and the front door were approximately $13 \mathrm{~m} / \mathrm{s}(29 \mathrm{mph})$, which was faster than the imposed wind speed $(9 \mathrm{~m} / \mathrm{s}$ or $20 \mathrm{mph}$ ) because of the addition of the buoyancy of the fire plume. The model temperatures increased through the stairwell doorway to between $400{ }^{\circ} \mathrm{C}$ and $425^{\circ} \mathrm{C}\left(750^{\circ} \mathrm{F}\right.$ to $\left.800^{\circ} \mathrm{F}\right)$ and through the front door to approximately $375^{\circ} \mathrm{C}\left(700^{\circ} \mathrm{F}\right)$. From the approximate timeline (Table 4.1), the front door was forced closed due to airflow pushing against it, $207 \mathrm{~s}$ into the simulation. Figures 5.4 and 5.5 show the conditions $1 \mathrm{~s}$ prior to and after the front door closed. The figures show that while the closed door stopped significant flow through the stairwell door and onto the first floor, the temperature hazard for the firefighters (temperatures at or above $400{ }^{\circ} \mathrm{C}$ or $750{ }^{\circ} \mathrm{F}$ ) remained.

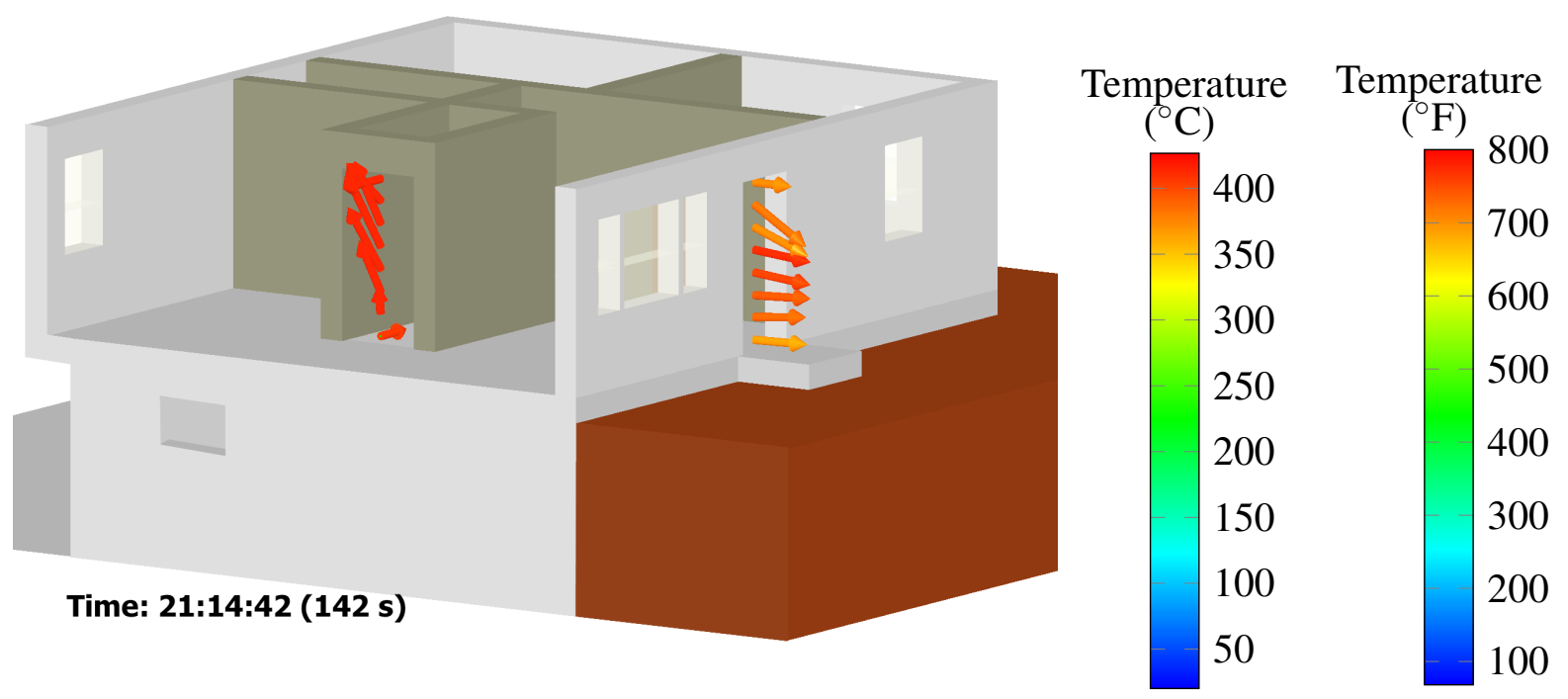

Figure 5.3: Flow path vectors at the front door and the top of the stairwell $42 \mathrm{~s}$ after the front door was opened, at the estimated time of first floor entry. 

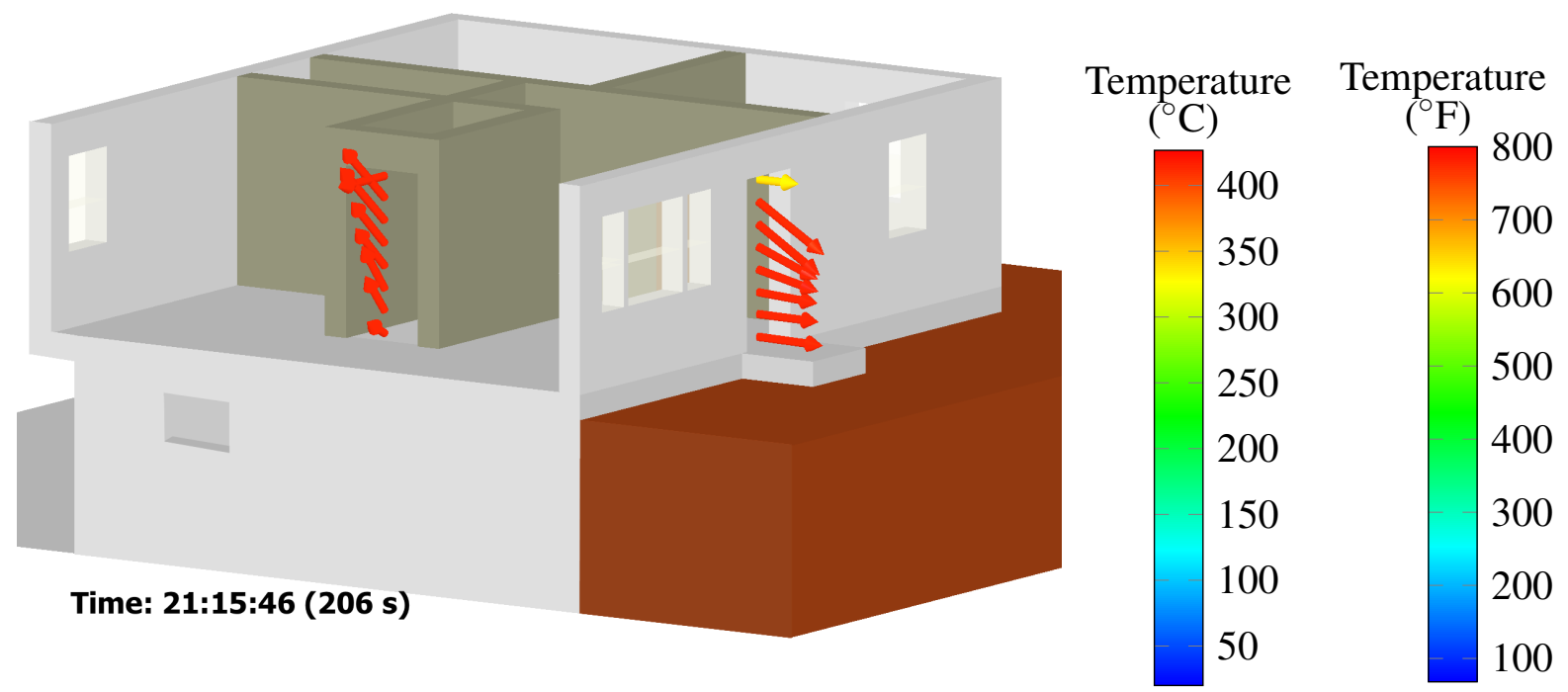

Figure 5.4: Flow path vectors at the front door and the top of stairwell $1 \mathrm{~s}$ before the front door was closed.

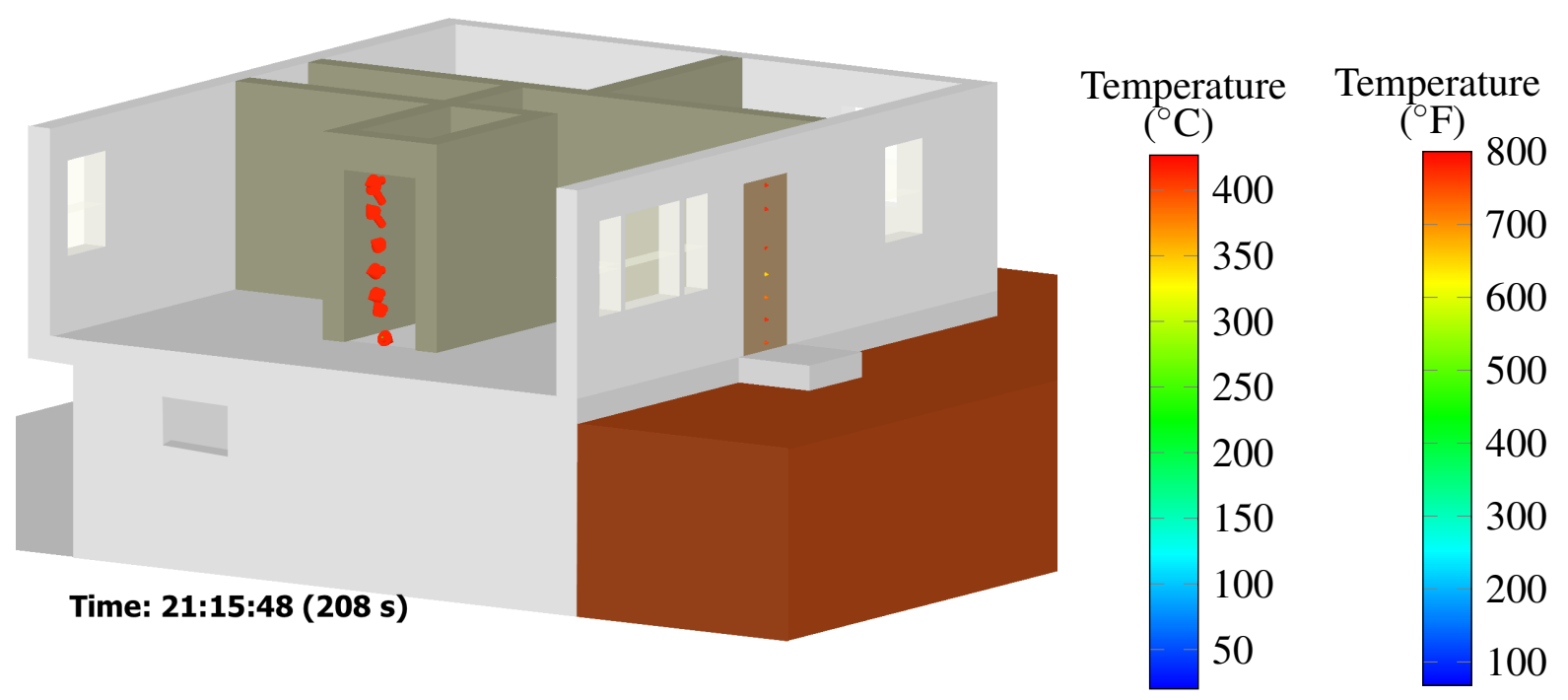

Figure 5.5: Flow path vectors at the front door and the top of stairwell $1 \mathrm{~s}$ after the front door was closed. 


\subsection{Assessing the Hazard}

A person is susceptible to second-degree burn injuries if skin temperatures exceed $55^{\circ} \mathrm{C}\left(130^{\circ} \mathrm{F}\right)[26]$. Although firefighters wear protective gear, gear only offers a finite amount of protection. The polycarbonate material in the facepiece of a self-contained breathing apparatus begins to soften when the material temperature reaches approximately $140{ }^{\circ} \mathrm{C}\left(284^{\circ} \mathrm{F}\right)$ [27]. Structural fire fighting coats and pants are tested to withstand temperatures up to $260^{\circ} \mathrm{C}\left(500^{\circ} \mathrm{F}\right)$ or $10 \mathrm{~kW} / \mathrm{m}^{2}$ [25] for less than $2.5 \mathrm{~min}$. Exposure to elevated temperatures can result in a significant amount of heat transferred to the firefighter, putting him or her at risk.

Figures 5.6 to 5.8 show two simulated interior views of temperature contours at particular snapshots in time. The top image is a planar view through the middle of the front door (from the front to the back of the house), which shows the conditions in the living area on the first floor and the conditions in the basement just past the bottom of the stairs. The bottom image shows temperature contours through the middle of the interior stairwell which connected the basement to the first floor of the structure (looking from the rear of the structure towards the front). Prior to the front door being opened, (Fig. 5.6 shows that temperatures in excess of $200{ }^{\circ} \mathrm{C}\left(400{ }^{\circ} \mathrm{F}\right)$ were confined to the basement of the structure: specifically the rear of the structure and under the stairwell. One second after the door was opened, hazard in the structure increased with the most drastic change occurring at the top of the stairwell as peak simulated temperatures exceeded $400{ }^{\circ} \mathrm{C}\left(750^{\circ} \mathrm{F}\right)$. At the approximate time firefighters made entry to the first floor, Fig. 5.8, the conditions within the flowpath (interior stairwell through front door) had become more severe with simulated temperatures in excess of $400{ }^{\circ} \mathrm{C}\left(750{ }^{\circ} \mathrm{F}\right)$, for which a fully protected firefighter would be susceptible to burn injuries. These high-hazard conditions within the flowpath remained until the HRR was reduced by the simulated action of applying water on the fire.

Based on these results and the simulation results shown in Sections 4.3 and 4.4, after the front door was opened, the simulated flow path temperatures in the interior stairwell were in excess of $400{ }^{\circ} \mathrm{C}\left(750^{\circ} \mathrm{F}\right)$ and the flow velocities were in excess of $9 \mathrm{~m} / \mathrm{s}(20 \mathrm{mph})$. The conditions in the interior stairwell changed from tenable to high-hazard very rapidly following the opening of the front door. Within the structure, the hot gases and smoke were moving along the flow path from the basement towards the door located on the front side of the structure via the interior stairwell. The simulated temperatures are consistent with the post-incident conditions that were documented in the interior stairwell.

Ongoing research and experimental work is being conducted by NIST to gain a better understanding of convective heat transfer to firefighter personal protective equipment, including firefighting gear, helmets, self-contained breathing apparatuses, etc. The goal of this ongoing research is to parameterize various flow path conditions (elevated temperatures and velocities) and determine their effect on the rate of heat transfer and amount of energy storage in firefighting safety equipment. 


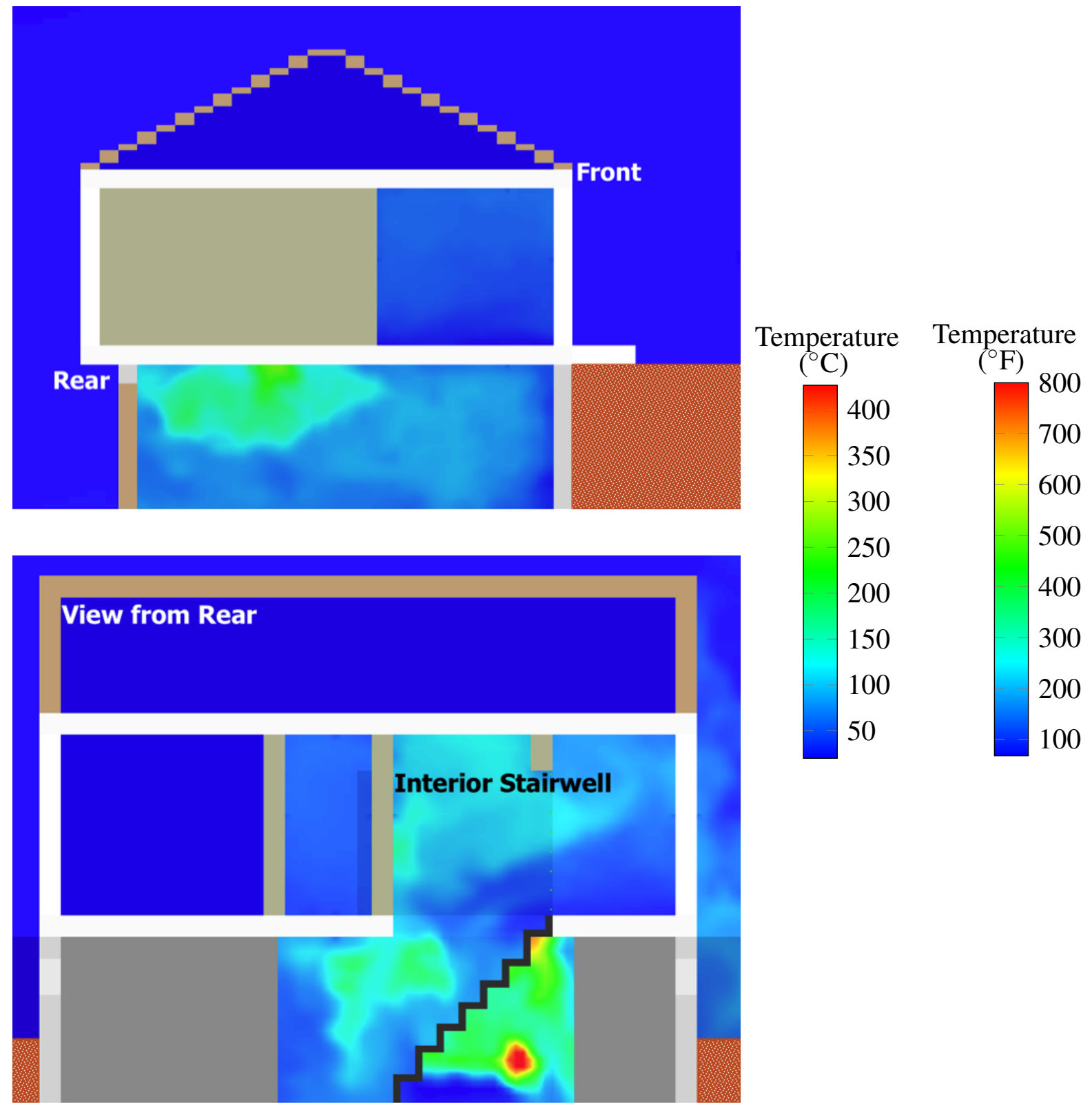

Figure 5.6: Interior temperature contours $1 \mathrm{~s}$ before the front door was opened (21:13:59). The top snapshot shows temperatures on the first floor and basement on the plane that runs through the center of the front door. The bottom snapshot shows temperatures on the first floor and basement on the plane that runs through the center of the interior stairwell doorway. 


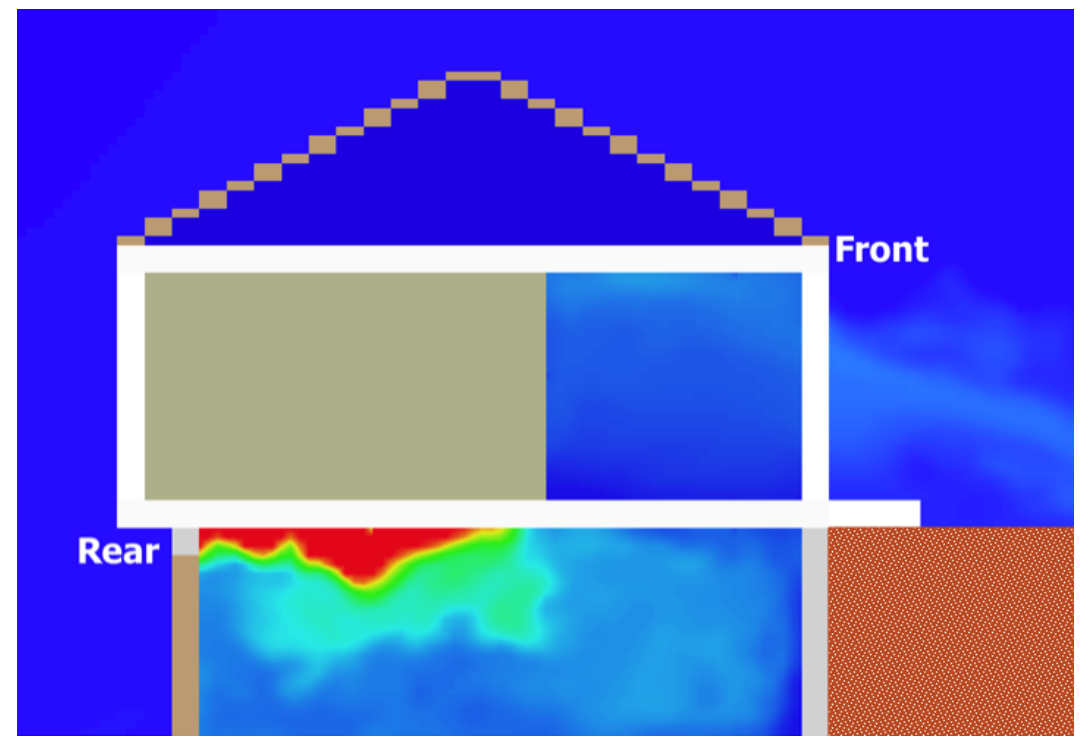

Temperature Temperature

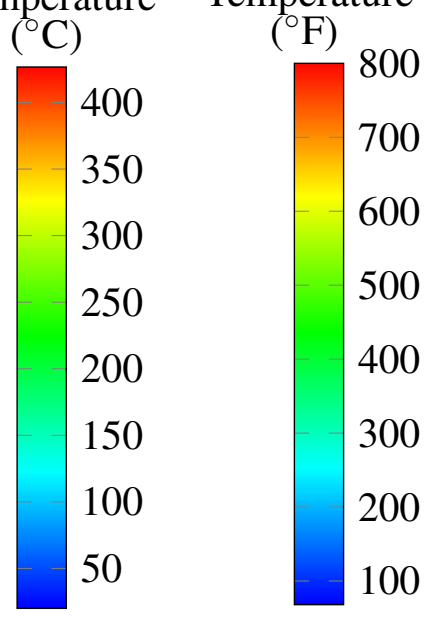

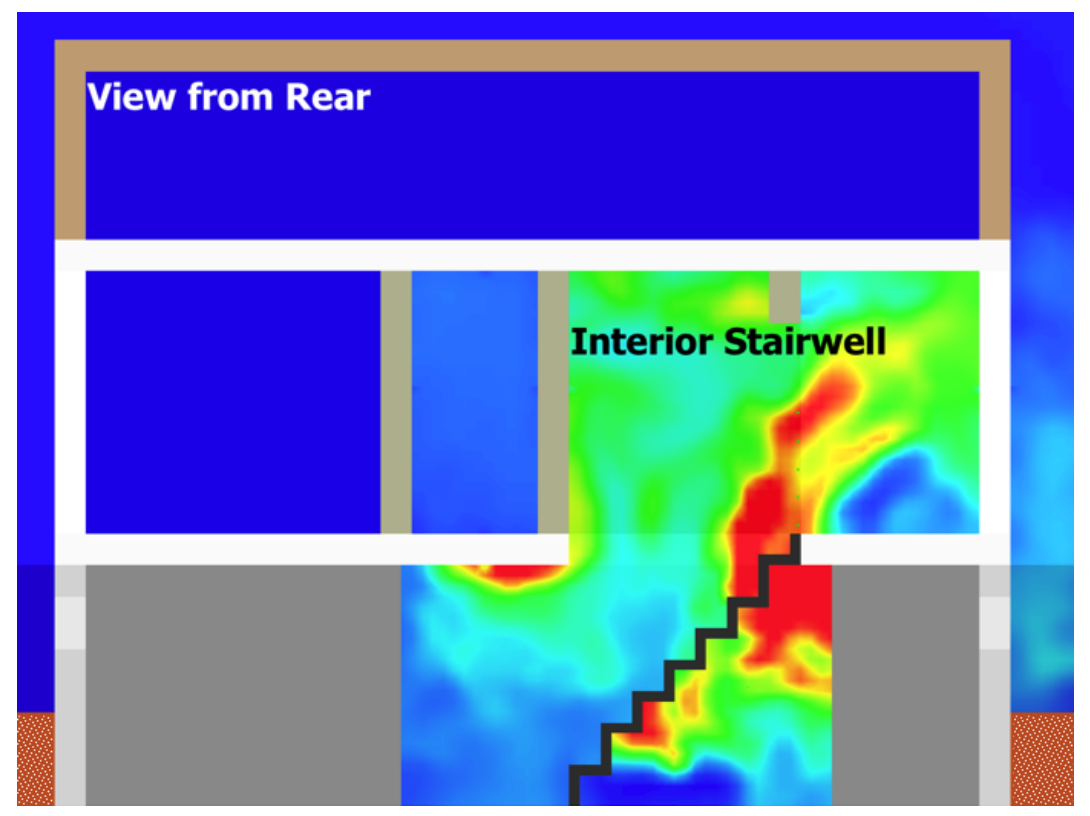

Figure 5.7: Interior temperature contours $1 \mathrm{~s}$ after the front door was opened (21:14:01). The top snapshot shows temperatures on the first floor and basement on the plane that runs through the center of the front door. The bottom snapshot shows temperatures on the first floor and basement on the plane that runs through the center of the interior stairwell doorway. 


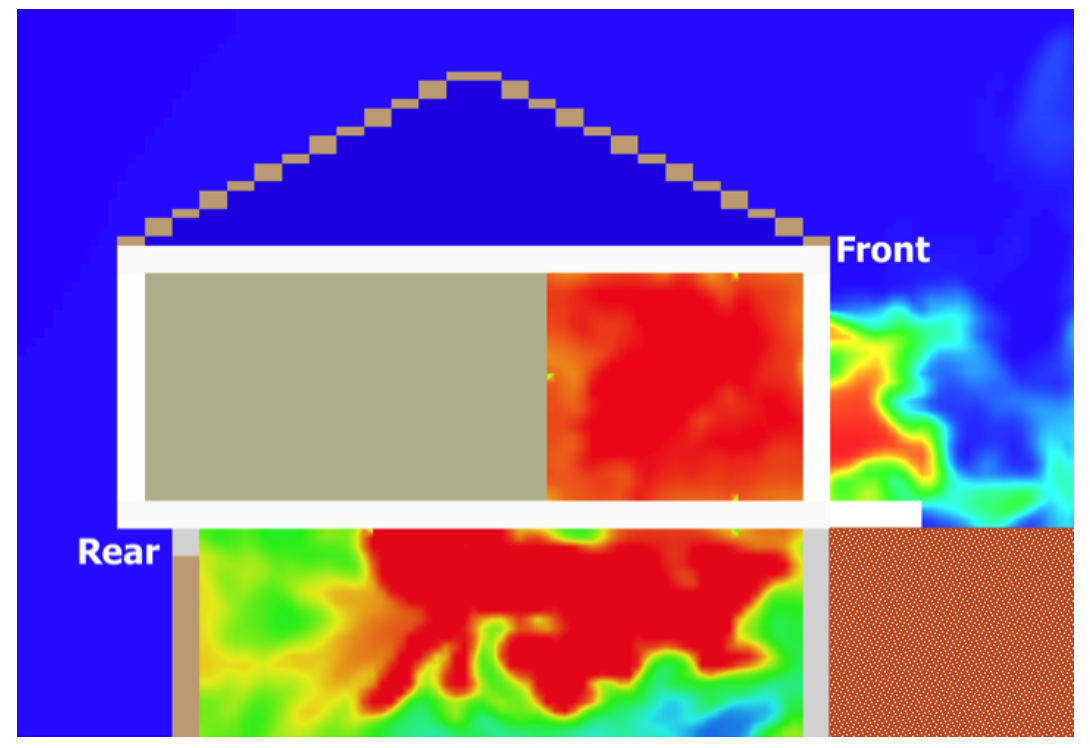

Temperature Temperature

\begin{tabular}{|l|l|l|}
$\left({ }^{\circ} \mathrm{C}\right)$ & $\left({ }^{\circ} \mathrm{F}\right)$ \\
400 & & 800 \\
350 & 700 \\
300 & 600 \\
250 & & 500 \\
200 & 400 \\
150 & 300 \\
100 & 200 \\
50 & \\
50
\end{tabular}

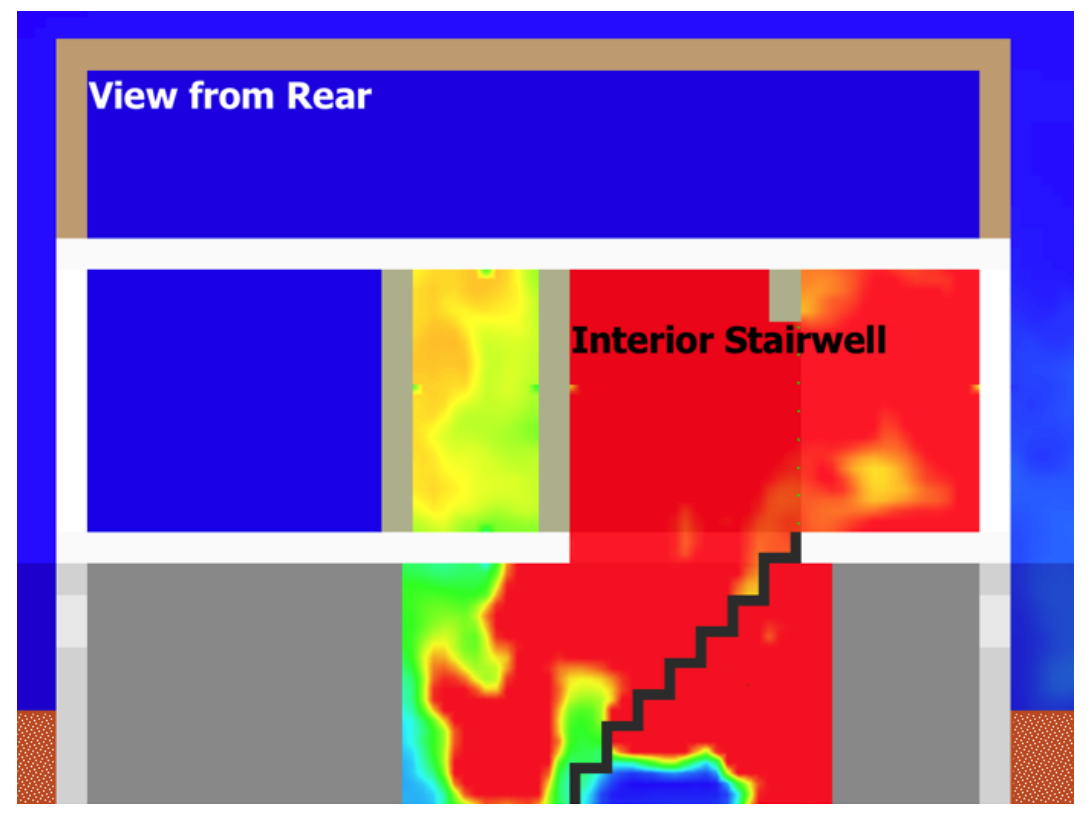

Figure 5.8: Interior temperature contours as firefighters made entry to the structure (21:14:42). The top snapshot shows temperatures on the first floor and basement on the plane that runs through the center of the front door. The bottom snapshot shows temperatures on the first floor and basement on the plane that runs through the center of the interior stairwell doorway. 


\subsection{Tactical Considerations}

In this fire incident, the initial failure of the basement windows with strong incident winds on the rear side of the structure coincided with a rapid change in the thermal conditions in the interior stairwell and first floor after the front door to the structure was opened. The open front door resulted in the establishment of a flow path within the interior stairwell from the high pressure side of the structure to the low presure side with highly hazardous conditions.

The interior stairwell acted as a chimney for hot gases in the basement to flow towards regions of lower pressure and vent openings located on the front side of the structure. Firefighters should avoid placing themselves within a flow path where elevated temperatures and flow velocities can present hazardous conditions and increase the rate of heat transfer to the firefighter via convection. A $360^{\circ}$ scene size-up by arriving firefighters can help determine the location of the fire and identify potential flow paths within a structure. Door control can also be used to avoid creating inlet and outlet vents that could result in the establishment of a flow path.

First suppression efforts should take place at the same level as the fire (i.e. fight basement fires from the basement level) with the wind at the back of firefighters. Ongoing research by NIST, Underwriters Laboratories (UL), and others has demonstrated that applying water from the exterior into the fire area of a structure (prior to the start of interior operations) can significantly improve the safety of firefighters by reducing the thermal hazard from the fire and reducing the potential for developing high velocity hot gas flows within the structure [17, 18].

There have been many previous fire incidents [28-42] in which changes in the flow paths are thought to have had an adverse impact on firefighter and occupant safety. Table 5.1 lists the NIOSH investigation reports from the past 15 years in which it could be determined that a flow path played a role in the related incident. This table lists the NIOSH report number, the outcome, and a brief description of the flow path details.

Based on a review of these incidents, it is clear that fires with rapidly developing or changing ventilation may lead to flow paths that are a significant hazard to the fire service during a response. The development of (or changes to) a flow path could be caused by the failure of a component of the structure, such as a door, window, or portion of a ceiling, wall or floor. Environmental conditions such as wind can generate hazardous thermal conditions within a flow path. Uncoordinated ventilation procedures can also be the cause of increased thermal hazards within a flow path. 
Table 5.1: Flow path related LODD/LODI incidents.

\begin{tabular}{|c|c|c|}
\hline NIOSH Report No. & No. of LODDs/LODIs & Flow Path Details \\
\hline 99-F01 [28] & 3 LODDs & $\begin{array}{l}\text { From apartment into hallway on 10th } \\
\text { floor of high-rise apartment building }\end{array}$ \\
\hline 99-F21 [29] & $\begin{array}{l}2 \text { LODDs } \\
2 \text { LODIs }\end{array}$ & Basement to 1 st floor \\
\hline F2000-04 [30] & $\begin{array}{l}3 \text { LODDs } \\
3 \text { civilian deaths }\end{array}$ & 1st floor to 2 nd floor \\
\hline F2000-16 [31] & $\begin{array}{l}1 \text { LODD } \\
1 \text { LODI } \\
1 \text { civilian death }\end{array}$ & $\begin{array}{l}\text { 2nd floor hallway through } \\
\text { 2nd floor apartment }\end{array}$ \\
\hline F2000-23 [32] & $\begin{array}{l}1 \text { LODD } \\
2 \text { LODIs }\end{array}$ & $\begin{array}{l}\text { From ground level to } 1 \text { st floor then to } \\
\text { 2nd floor, flow exited through ceiling }\end{array}$ \\
\hline F2000-43 [33] & $\begin{array}{l}1 \text { serious LODI } \\
2 \text { other LODIs }\end{array}$ & 1 st floor to 2 nd floor \\
\hline F2004-02 [34] & 1 LODD & 1st floor to basement \\
\hline F2005-02 [35] & $\begin{array}{l}1 \text { LODD } \\
4 \text { LODIs }\end{array}$ & Rear to front of the building \\
\hline F2005-04 [36] & $\begin{array}{l}1 \text { LODD } \\
9 \text { LODIs }\end{array}$ & Basement to 1 st floor \\
\hline F2007-09 [37] & $\begin{array}{l}1 \text { LODD } \\
2 \text { LODIs }\end{array}$ & $\begin{array}{l}3 \text { story training burn - flow through } \\
\text { all levels }\end{array}$ \\
\hline F2007-35 [38] & 4 LODIs & 1st floor to 2 nd floor \\
\hline F2009-11 [39] & 2 LODDs & Rear to front of the building \\
\hline F2011-13 [40] & 2 LODDs & $\begin{array}{l}\text { Lower level up stairs and through } \\
\text { entry door and garage }\end{array}$ \\
\hline F2011-31 [41] & $1 \mathrm{LODD}$ & Fire extended from lower level apartment \\
\hline F2012-28 [42] & $\begin{array}{l}1 \text { LODD } \\
1 \text { LODI }\end{array}$ & $\begin{array}{l}\text { Attic fire extended into closed } \\
\text { porch and then into } 2 \text { nd floor }\end{array}$ \\
\hline
\end{tabular}




\section{Section 6}

\section{Summary}

Fire Dynamics Simulator was used to provide insight into the fire dynamics of a fire that occurred within a single-story, single-family residential structure in Riverdale Heights, MD, that resulted in the serious injury of two firefighters. The fuel, fire size, and fire growth rate that were used in the FDS simulation were estimated by taking into account all of the available information including the post incident report from Prince George's Country Fire/EMS [10], post-incident pictures, and relevant literature. This resulted in a maximum specified source fire of approximately $8.5 \mathrm{MW}$ in the basement. Based on the limited ventilation conditions in the basement, the FDS simulation results indicated that before the front door was opened, there was combustion occurring outside the structure at the rear basement windows which had failed prior to fire department arrival. Once the front door was opened, there was sufficient oxygen for combustion to occur within the structure, with intermittent flaming combustion on the first floor.

The fire originated in the basement, and the interior stairwell acted as a chimney for hot gases in the basement to flow towards regions of lower pressure through the open front door of the structure. After the front door was opened, a flow path was established between the basement and the front side of the structure (the front door). The opening of the front door resulted in a rapid change in the conditions within the flow path. In the interior stairwell, the flow velocities were greater than $9 \mathrm{~m} / \mathrm{s}(20 \mathrm{mph})$ and the temperature of the gases was estimated to be in excess of $400{ }^{\circ} \mathrm{C}\left(750{ }^{\circ} \mathrm{F}\right)$, which puts fully protected firefighters at risk for burn injuries.

Two firefighters were located in the flow path between the basement and the doors on the front side of the structure. One firefighter was able to break a window to escape the hazardous conditions and after a call for assistance, the second firefighter was removed from the structure and immediate medical treatment was provided. The two firefighters were transported to the local medical center where they were treated for their injuries. Five other firefighters were injured onscene and transported to the hospital for treatment. 


\section{Section 7}

\section{Acknowledgments}

The authors would like to thank Chief Marc Bashoor of the Prince George's County Fire/EMS Department for their assistance with this study and their dedication to improving firefighter safety. The authors would like to thank members of the Safety Investigation Team for compiling the report: Deputy Chief Scott Hoglander, Battalion Chief Sayshan Conver-White, Chief Richard Bowers, Deputy Chief William Goldfeder, Assistant Chief Michael Nelson, Volunteer Safety Division Chief Stefan Ganset, Paramedic Captain Roland Berg, Lieutenant Philip Bird, Lieutenant Daniel Schrader, Investigator Aaron Tyler, Fire Protection Engineer Lee McCarthy, President Charles Walker, and Administrative Aide Xiomara Lozano-Chevez. The authors would also like to thank John Culbertson, Director of the Montana Fire Services Training School, for his assistance in researching and compiling the flow path related LODD/LODI incidents shown in Table 5.1. Finally, the authors would like to thank Joseph Willi of the University of Illinois Urbana-Champaign for his assistance in creating dimensioned drawings of the structure. 


\section{References}

[1] D. Madrzykowski and R.L. Vettori. Simulation of the Dynamics of the Fire at 3146 Cherry Road NE Washington D.C., May 30, 1999. NISTIR 6510, National Institute of Standards and Technology, Gaithersburg, Maryland, April 2000.

[2] D. Madrzykowski, G.P. Forney, and W.D. Walton. Simulation of the Dynamics of a Fire in a Two-Story Duplex - Iowa, December 22, 1999. NISTIR 6854, National Institute of Standards and Technology, Gaithersburg, Maryland, January 2002.

[3] R.L. Vettori, D. Madrzykowski, and W.D. Walton. Simulation of the Dynamics of a Fire in a One-Story Restaurant - Texas, February 14, 2000. NISTIR 6923, National Institute of Standards and Technology, Gaithersburg, Maryland, October 2002.

[4] N. Bryner, S.P. Fuss, B.W. Klein, and A.D. Putorti. Technical Study of the Sofa Super Store Fire, South Carolina, June 18, 2007. NIST Special Publication 1118, National Institute of Standards and Technology, Gaithersburg, MD, March 2011.

[5] A. Barowy and D. Madrzykowski. Simulation of the Dynamics of a Wind-Driven Fire in a Ranch-Style House - Texas. NIST Technical Note 1729, National Institute of Standards and Technology, Gaithersburg, Maryland, 2012.

[6] C.G. Weinschenk, K.J. Overholt, and D. Madrzykowski. Simulation of an Attic Fire in a Wood Frame Residential Structure - Chicago, IL. NIST Technical Note 1838, National Institute of Standards and Technology, Gaithersburg, Maryland, 2014.

[7] K.J. Overholt, C.G. Weinschenk, and D. Madrzykowski. Simulation of a Fire in a Hillside Residential Structure - San Francisco, CA. NIST Technical Note 1856, National Institute of Standards and Technology, Gaithersburg, Maryland, 2014.

[8] K. McGrattan, S. Hostikka, R. McDermott, J. Floyd, C. Weinschenk, and K. Overholt. Fire Dynamics Simulator, User's Guide. National Institute of Standards and Technology, Gaithersburg, Maryland, USA, and VTT Technical Research Centre of Finland, Espoo, Finland, sixth edition, September 2013.

[9] G.P. Forney. Smokeview (Version 6), A Tool for Visualizing Fire Dynamics Simulation Data, Volume I: User's Guide. NIST Special Publication 1017-1, National Institute of Standards and Technology, Gaithersburg, Maryland, May 2013. 
[10] S.K. Hoglander and S. Conver-White. House Fire with Significant Firefighter Injuries Riverdale Heights, MD. Safety Investigation Team Report, Prince George's County Fire/Emergency Medical Services Department, Lanham, Maryland, 2013.

[11] K. McGrattan, S. Hostikka, R. McDermott, J. Floyd, C. Weinschenk, and K. Overholt. Fire Dynamics Simulator, Technical Reference Guide, Volume 2: Verification. National Institute of Standards and Technology, Gaithersburg, Maryland, USA, and VTT Technical Research Centre of Finland, Espoo, Finland, sixth edition, September 2013.

[12] K. McGrattan, S. Hostikka, R. McDermott, J. Floyd, C. Weinschenk, and K. Overholt. Fire Dynamics Simulator, Technical Reference Guide, Volume 3: Validation. National Institute of Standards and Technology, Gaithersburg, Maryland, USA, and VTT Technical Research Centre of Finland, Espoo, Finland, sixth edition, September 2013.

[13] K. McGrattan, S. Hostikka, R. McDermott, J. Floyd, C. Weinschenk, and K. Overholt. Fire Dynamics Simulator, Technical Reference Guide, Volume 1: Mathematical Model. National Institute of Standards and Technology, Gaithersburg, Maryland, USA, and VTT Technical Research Centre of Finland, Espoo, Finland, sixth edition, September 2013.

[14] A. Tewarson. SFPE Handbook of Fire Protection Engineering, chapter Generation of Heat and Gaseous, Liquid, and Solid Products in Fires. National Fire Protection Association, Quincy, Massachusetts, fourth edition, 2008.

[15] V. Babrauskas and S. Grayson. Heat release in fires. Taylor \& Francis, 1990.

[16] American Society for Testing and Materials, West Conshohocken, Pennsylvania. ASTM E 1355-04, Standard Guide for Evaluating the Predictive Capabilities of Deterministic Fire Models, 2004.

[17] D. Madrzykowski and S. Kerber. Fire Fighting Tactics Under Wind Driven Conditions: Laboratory Experiments. NIST Technical Note 1618, National Institute of Standards and Technology, Fire Research Division Engineering Laboratory, 2009.

[18] S. Kerber and D. Madrzykowski. Fire fighting tactics under wind driven fire conditions: 7 story building experiments. NIST Technical Note 1629, National Institute of Standards and Technology, Fire Research Division Engineering Laboratory, 2009.

[19] K. Ghazi Wakili, E. Hugi, L. Wullschleger, and T.H. Frank. Gypsum Board in Fire - Modeling and Experimental Validation. Journal of Fire Sciences, 25(3):267-282, 2007.

[20] F. P. Incropera and D. P. De Witt. Fundamentals of Heat and Mass Transfer. John Wiley and Sons, New York, 4th edition, 1996.

[21] C.M. Beal, M. Fakhreddine, and O.A. Ezekoye. Effects of leakage in simulations of positive pressure ventilation. Fire Technology, 45(3):257-286, 2009.

[22] K. Hill, J. Dreisbach, F. Joglar, B. Najafi, K. McGrattan, R. Peacock, and A. Hamins. Verification and Validation of Selected Fire Models for Nuclear Power Plant Applications. NUREG1824, United States Nuclear Regulatory Commission, Washington, DC, 2007. 
[23] W.D. Walton and P.H. Thomas. SFPE Handbook of Fire Protection Engineering, chapter Estimating Temperatures in Compartment Fires. National Fire Protection Association, Quincy, Massachusetts, 4th edition, 2008.

[24] D. Stroup and A. Lindeman. Verification and Validation of Selected Fire Models for Nuclear Power Plant Applications. NUREG-1824, Supplement 1, United States Nuclear Regulatory Commission, Washington, DC, 2013.

[25] National Fire Protection Association, Quincy, Massachusetts. NFPA 1971, Standard on Protective Ensembles for Structural Fire Fighting and Proximity Fire Fighting, 2013.

[26] American Society for Testing and Materials, West Conshohocken, Pennsylvania. ASTM C 1055-03, Standard Guide for Heated System Surface Conditions that Produce Contact Burn Injuries, 2003.

[27] A. Mensch and N. Bryner. Emergency first responder respirator thermal characteristics: Workshop proceedings. NIST Special Publication 1123, US Department of Commerce, Engineering Laboratory, National Institute of Standards and Technology, 2011.

[28] T.A. Pettit, F. Washenitz, and K. Cortez. Three Fire Fighters Die in a 10-Story High-Rise Apartment Building - New York. NIOST 99-F01, NIOSH Fire Fighter Fatality Investigation and Prevention Program, 1999.

[29] F. Washenitz, R. Braddee, T.A. Pettit, and E. Schmidt. Two Fire Fighters Die and Two Are Injured in Townhouse Fire - District of Columbia. NIOSH 99-F21, NIOSH Fire Fighter Fatality Investigation and Prevention Program, 1999.

[30] T.P Mezzanotte, E. Schmidt, T.A. Pettit, and D. Castillo. Structure Fire Claims the Lives of Three Career Fire Fighters and Three Children - Iowa. NIOSH F2000-04, NIOSH Fire Fighter Fatality Investigation and Prevention Program, 2001.

[31] M. McFall and E. Schmidt. Arson Fire Claims the Life of One Volunteer Fire Fighter and One Civilian and Severely Injures Another Volunteer Fire Fighter - Michigan. NIOSH F2000-16, NIOSH Fire Fighter Fatality Investigation and Prevention Program, 2001.

[32] M. McFall, R. Braddee, and T. Mezzanotte. Career Fire Fighter Dies and Three Are Injured In a Residential Garage Fire - Utah. NIOSH F2000-23, NIOSH Fire Fighter Fatality Investigation and Prevention Program, 2000.

[33] M. McFall. A Volunteer Assistant Chief Was Seriously Injured and Two Volunteer Fire Fighters Were Injured While Fighting a Townhouse Fire - Delaware. NIOSH F2000-43, NIOSH Fire Fighter Fatality Investigation and Prevention Program, 2001.

[34] S. Berardinelli, B. Oerter, J. Tarley, and T. Merinar. Career Battalion Chief and Career Master Fire Fighter Die and Twenty - Nine Career Fire Fighters are Injured during a Five Alarm Church Fire - Pennsylvania. NIOSH F2004-02, NIOSH Fire Fighter Fatality Investigation and Prevention Program, 2006. 
[35] R.E. Koedam, T. Merinar, and M. Bowyer. One Probationary Career Firefighter Dies and Four Career Firefighters are Injured at a Two-Alarm Residential Structure Fire - Texas. NIOSH F2005-02, NIOSH Fire Fighter Fatality Investigation and Prevention Program, 2007.

[36] M. McFall, V. Lutz, and S. Berardinelli. Career Fire Fighter Dies While Exiting Residential Basement Fire - New York. NIOSH F2005-04, NIOSH Fire Fighter Fatality Investigation and Prevention Program, 2006.

[37] J. Tarley, S. Berardinelli, and T. Merinar. Career Probationary Fire Fighter Dies While Participating in a Live - Fire Training Evolution at an Acquired Structure - Maryland. NIOSH F2007-09, NIOSH Fire Fighter Fatality Investigation and Prevention Program, 2008.

[38] R. Braddee, M. Bowyer, and S. Berardinelli. Four Career Fire Fighters Injured While Providing Interior Exposure Protection at a Row House Fire - District of Columbia. NIOSH F2007-35, NIOSH Fire Fighter Fatality Investigation and Prevention Program, 2008.

[39] T. Merinar, J. Tarley, and S.T. Miles. Career Probationary Fire Fighter and Captain Die as a Result of Rapid Fire Progression in a Wind-Driven Residential Structure Fire - Texas. NIOSH F2009-11, NIOSH Fire Fighter Fatality Investigation and Prevention Program, 2010.

[40] M. Bowyer and M. Loflin. A Career Lieutenant and Fire Fighter/Paramedic Die in a Hillside Residential House Fire - California. NIOSH F2011-13, NIOSH Fire Fighter Fatality Investigation and Prevention Program, 2012.

[41] M. Loflin, T. Hales, and S.T. Miles. Career Fire Fighter Dies during Fire-Fighting Operations at a Multi-family Residential Structure Fire - Massachusetts. NIOSH F2011-31, NIOSH Fire Fighter Fatality Investigation and Prevention Program, 2013.

[42] M.E. Bowyer, S.C. Wertman, and M. Loflin. Career Captain Sustains Injuries at a 2-1/2 Story Apartment Fire then Dies at Hospital - Illinois. NIOSH F2012-28, NIOSH Fire Fighter Fatality Investigation and Prevention Program, 2013. 


\section{Appendix A}

\section{Dimensioned Drawings}

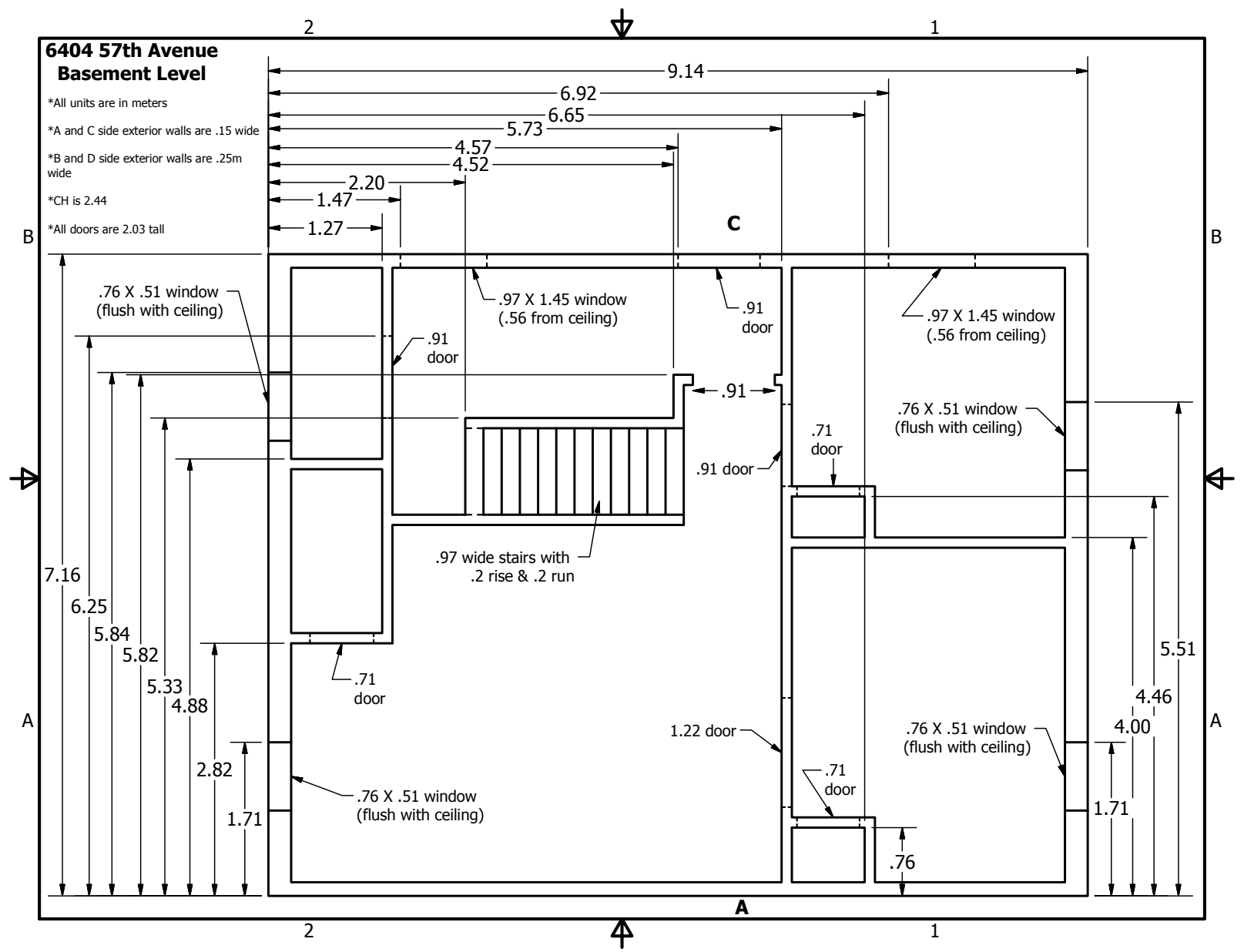

Figure A.1: Dimensioned drawing of the basement. The measurements are accurate to within $15 \mathrm{~cm}$ (6 in). 


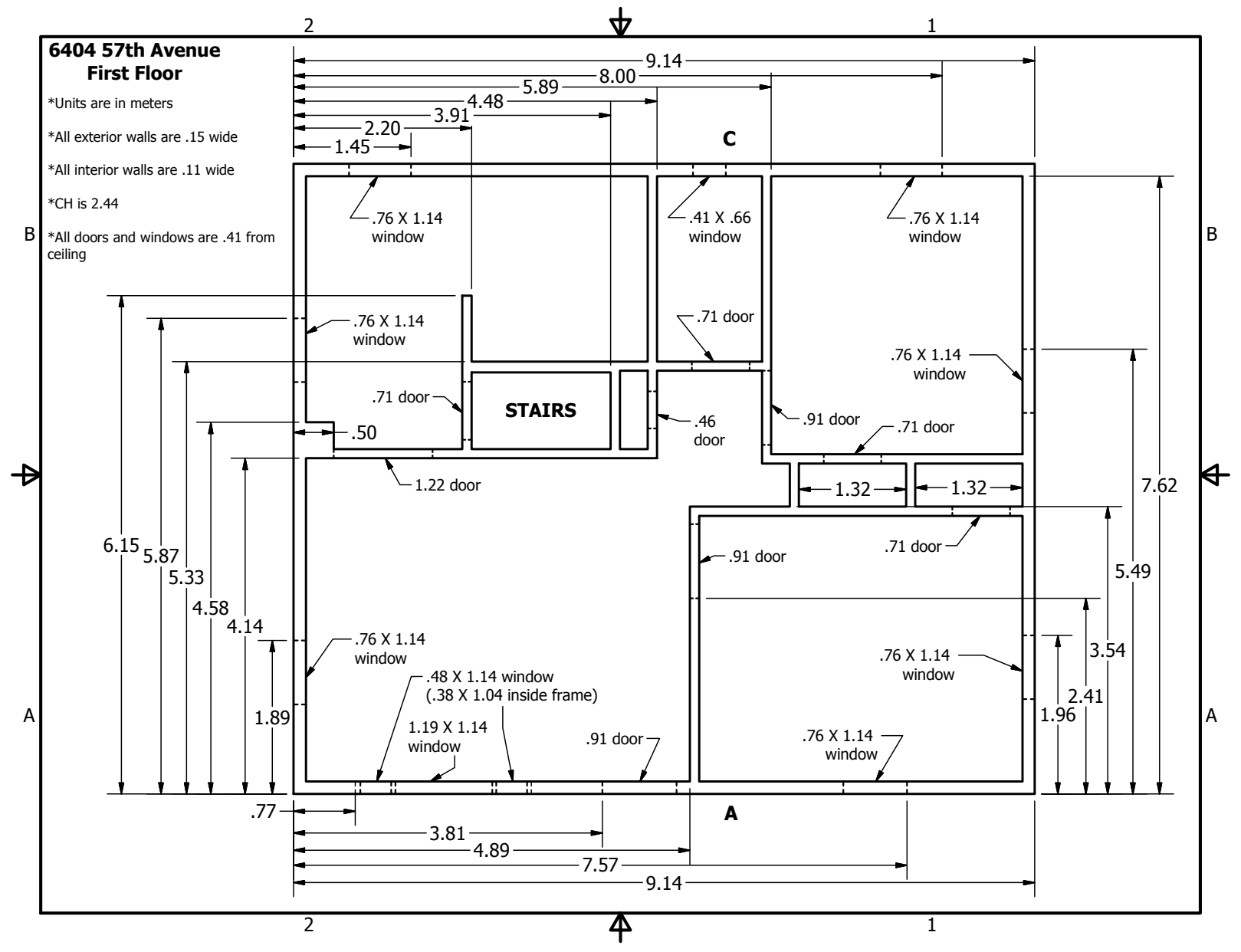

Figure A.2: Dimensioned drawing of the first floor. The measurements are accurate to within $15 \mathrm{~cm}$ (6 in). 